\title{
Privacy: A Review and CritiQue of The LITERATURE
}

\author{
RICHARD B. BRUYER ${ }^{\circ}$
}

It seems trite to say privacy is valuable. The Supreme Court of Canada has emphasized that privacy is worthy of constitutional protection. Scholars tend to agree that privacy is a findamental moral and political concept. The consensiss appears to end. however, when privacy in theory approaches privacy in practice. As a broad and evanescent concept. opinions differ as to what interests or values the protection of privacy is designed to achieve. The prevailing conceptions of privacy - six of which have been identified -- fall prey to substantive criticisms from which, the atwhor contends, they camos recover. First, they suffer from intuifionism. That is, they offer an intuitive approach of what makes things "privafe" and incorrectly assume that we all approach privacy with a common anderstanding of the concept. or concepts, that the term "privacy" expresses. Further. the standing conceptions of privacy depend upon and serve the concept of privacy as libern' which itself is nawed. "Liberty" is seen as a form of licence. protecting - in its most crude form - an individual's right to do as he or she pleases. So viewed, it is not particularly surprising to see privacy attacked when competing "liberty" isswex are at stake. Given the substantial criticisms with the prevailing conceptions of privacy. it may be worthuthile to reconsider the present paradigm agains/ which privacy is conceived. I/ may be that privacy is better conceived of as an equality issue, not a liberty issue. The focus should shiff away from conceptualizing privacy as a prerequisite for preventing invasions of various /iberty interests to one of "maintaining conditions" that will make the exercise of those liberty interests possible. By. limiting the ambir of privacy. ne man indeed strengthen it.
Il semble oiseux de dire que le respect de la vie privee est précieux. Le Cour supréme du Canada a fair valoir que le respect de la vie prive mérike la protection de la Comstimution. Les inudits semblent daccord que ce respect est in concept moral et poliniguc fondamental. II "y a copendant plas de comsensus lorsque l'on passe de la thioric a la pratique. C"est un concep! vaste et evanescent, et les opinions different sur lintèrè ou la valeur que la protection de la vie privee devrail apporter. Les idées dominames sur le respect de la vie privéc, don les six grandes on été identifiées, devienmem la proie de critiques dom. comme le fait remarquer lanteur, elles ne pewven pas se relever. Tout d'abord, elles souffent d'intuitionmisme, c'est-àdire qu'elles proposent une demarche immitive à lëgard de ce' qui ast " prive " et suppose, à tort, que nous avons lous la mime comprehension du concept de " respect de la vie privé ". De plus, les idees habituelles sur ce respect dependent di concept de liberté qui est. Iui aussi, sans fondement. "Liberté" semble ètre considérée comme ume forme de licence. protégean dans sa forme la plus élementaire le droit d'une persome de faire d̀ son gré. II n'est donc pas particuliereme'nt surprenant gue le respect de la vie privee soif atraqué si on le compare anx questions de a liberfi " qui som en jeu. Compte temu des critiques à l'egard des idées dominantes relatives au respect de la vie privic, il peut ère urile d'examiner de nowvean le présent paradigme par rapport anquel le respect de la vie privée a dí conçu. Il se peut anssi que cet aspect convienne mieux à la question d'égalité que de liberté. Il faudrait éviter de conceptualiser le respect de la vie prive en tant que préalable pour prévenir les atleimtes aux diverse's libertés et s'en tenir au " maintien des conditions "qui permettrom l 'exercice de ces libertes. En limitam la portic du respect de la vie privice, nous pourrons peuteitre la renforcer.

\section{TABI.E OF CONTENTS}

1. INTRODUCTION ......................... 554

II. CURRENT ConcEPtIONS of PRIVACy $\ldots \ldots \ldots \ldots \ldots \ldots \ldots \ldots \ldots \ldots$

A. THE RIGHT TO BE LET ALONE $\ldots \ldots \ldots \ldots \ldots \ldots \ldots \ldots \ldots \ldots \ldots 58$

B. THE LIMITED ACCESS TO THE SELf (AUTONOMY) ........ 561

B. Comm., LL.B., LL.M., called to the Alberta Bar in 1992, now a contract lawyer with de Villars Jones, Edmonton. The author would like to thank Professor Ted DeCoste, who supervised his LL.M. thesis (from which this paper draws extensively) and whose insight and patience undoubledly improved the quality of the work. 
C. SECRECy/CONCEALMENT OF DISCREDITABLE

INFORMATION ........................ 562

D. Control over Personal Information ........... 564

E. Creation of SELF/Personhood and the

Preservation of One's Dignity ................... 566

F. Promotion of Intimacy and Relationships $\ldots \ldots \ldots \ldots \ldots . \ldots 68$

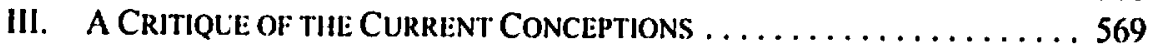

A. Summary of Standing Criticisms $\ldots \ldots \ldots \ldots \ldots \ldots \ldots 569$

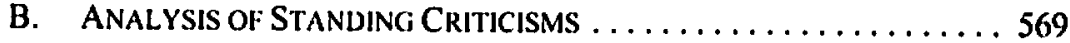

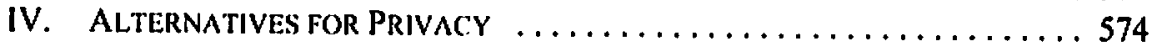

A. Combine Current Conceptions .................. 575

B. A Pragmatic Appronch to Conceptualizing

PrIVACY ............................. 580

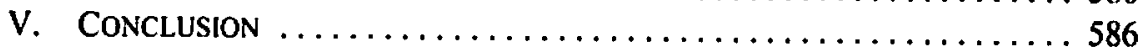

Privacy is a value so complex, so entangled in competing and contradictory dimensions, so engorged with various and distinct meanings, that I sometimes despair whether it can be usefully addressed at all.'

\section{INTRODUCTION}

It seems trite to say privacy is valuable. The Supreme Court of Canada has emphasized, on numerous occasions, that "[ $t$ ]he protection of privacy is a fundamental value in modem, democratic states,"2 worthy of constitutional protection for that reason alone, but having "profound significance for the public order" as well. ${ }^{3}$ Privacy has emerged as a fundamental value, not only for Canadian society but for human society as well, having found protection as the right against arbitrary interference with privacy in art. 12 of the Universal Declaration of Human Rights, ${ }^{4}$ and art. 17 of the Imternational Covenam on Civil and Political Rights.

The consensus appears to end, however, when privacy in theory approaches privacy in practice. As a "broad and somewhat evanescent concept," opinions differ as to what interests or values the protection of privacy is designed to achieve. Numerous examples abound. Two of Canada's privacy "experts," saddled with the responsibility of ensuring informational privacy - the Alberta privacy commissioner and the federal privacy commissioner - reached opposite conclusions in similar scenarios concerning whether prescriber information disclosed by pharmacists to a data collection company violates the

Robert C. Post, "Three Concepts of Privacy” (2001) 89 Geo. L.J. 2087 at 2087.

Dagg v. Camada (Minister of Finance), [1997] 2 S.C.R. 403 at para. 65 [Dagg].

R. v. Dymem. [1988] 2 S.C.R. 417 at 427 [Dymem].

GA Res. 217(III), UN GOAR. 3d Sess., Supp. No. 13. UN Doc. A/810)(1948), art 12: "No one shall be subjected to arbitrary interference with his privacy, family, home or correspondence, nor to attacks upon his honour and reputation. Everyone has the right to the protection of the law against such interference
or attacks."

19 Detember 1966, 999 U.N.T.S. 171, Can. T.A. 1976 No. 47, 6 I.L.M. 368 (entered into force 23 Manch 1976). See John D.R. Craig, "Invasion of Privacy and Charfer Values: The Common-Law Tort Awakens" (1997) 42 Mc.Gill L.J. 355. Dagg, supra note 2 at para. 67, in relation to defining the privacy interests protected by the Privacy $A C t$,
R.S.C. 1985 , c. P-21. 
prescribing physician's right to privacy. 'Two decisions by the Supreme Court of Canada appear to be inconsistent on whether disclosures of information pursuant to access to information requests violate individual privacy in particular cases. ${ }^{8}$ In the context of employee surveillance, two arbitrators reached different conclusions in cases involving the admissibility of surreptitious surveillance, both citing an employee's reasonable expectation of privacy, or lack thereof, in similar scenarios, as the basis for their decisions." In the context of the criminal law, there are numerous examples spanning dillerent jurisdictions and court levels where the judiciary rules a search and seizure violates s. 8 of the Charter ${ }^{10}$ in one scenario but does not in conceptually similar circumstances. For example, the Supreme Court held, in one case, that an accused does not have a reasonable expectation of privacy in his personal electric consumption records in his home," but, in another, ruled that the accused does have a reasonable expectation of privacy in his financial information at his bank. ${ }^{12}$ The Supreme Court of the United States, by contrast, came to the opposite conclusion as regards financial records in an earlier case in that country. ${ }^{13}$

It is not only privacy jurisprudence, as reflected in different results in these decisions, that appears to be inconsistent. Scholarly literature on privacy is rife with inconsistency on this score as well and must be held to have contributed to the piecemeal, patchwork approach to privacy by the judiciary. When speaking of privacy, scholars at one end of the spectrum contend that privacy promotes or protects relationships, ${ }^{14}$ one's personhood and the creation

- Alberta: Order H2002-003 between M/S Heallh Canoda and Alherta Pharmacisis and Pharmacies. An application for judicial review was commenced in the Alberta Court of Queen's Bench and appealed to the Alberta Court of Appeal (IMSS Heallh Canala Lal. 1: Alberta Information and Privacy. Commissioner) (2005), 371 A.R. 62, 2005 ABCA 325. Federal: PIPEDA Case Summay \#/5 (Letter from Privacy Commissioner, 2 October 2001), onlinc: Oflice of the Privacy Commissioner of Canada <www.privcom.gc.ca/media/an/wn_011002_c.asp>. Likewise, an application for judicial review was brought in the Federal Court and was appealed to the Federal Court of Appeal (Mahen v. IMS Heallh Canada (2003), 314 N.R. 393, 2003 FCA 462).

s Disclosure of personal employment information of RCMP members to aid in litigation was urdered in Canada (Information Commissioner) v: Canada (Commissioner of the Royal Camadian Moumed Police). [2003] I S.C.R. 66, 2003 SCC 8 [Information Commissiomer I: RCIIP]) disclosure of the expenses of a particular member ol Quebec's National $A$ ssembly was refused without the consent of the member in Macdonell v. Quebec (Commission d'aceis a /'information). [2002] 3 S.C. R. 661. 2002 SCC 71.

- Surveillance evidence excluded in Re Doman Forest Products L.kl. and I. W.A. Loc. I-357 (1990), 13 L.A.C. (4th) 275, Vickers; surveillance evidence admitted in Re Toronto Transis Commission and A.T.U. Loc. 113 (Fallon) (1999), 79 L.A.C. (41h) 85, Solomatenko.

Canadian Charter of Rights and Freedoms, Part I of the Constitution Act. 1982, being Schedule B to the Canada Act 1982 (U.K.), 1982. c. 11 [Charter].

" R. v. Plamt. [1993] 3 S.C.R. 281 at 293 [Plamt], where Sopinka J. held that s. 8 of the Charrer only protects "a biographical core of personal information" and that " $[1]$ he computer records investigated in the case at bar while revealing the pattern of electricity consumption in the residence cannot reasonably be said to reveal intimate delails of the appellant's life since electricity consumplion reveals very little about the personal lifestyle or privale decisions of the occupant of the residente."

Schreiber v. Canoda (Allorney General), [1998] I S.C.R. 84I [Sc/hreiher], where allhough the Court split on the applicability ol the Charfer for different reasons (i.e. the request for information was in a foreign financial institution (Swiss)), all agreed that financial information does tall with the "biological core of personal information" (Plant, ibid. at 293) that ought to be protected.

is Unifed States v. Miller, 425 U.S. 435 (1976).

is James Rachels. "Why Privacy is Important" (1975) 4 Philosophy and Public Affairs 323. 
of self, ${ }^{15}$ one's dignity, ${ }^{16}$ and even democracy ${ }^{17}$ and the rejection of totalitarianism. ${ }^{18}$ At the other end of the spectrum, scholars dismiss privacy as simply protecting property interests, ${ }^{19}$ as promulgating subordination of, and violence to, women by men, ${ }^{20}$ or as promoting, or at least rewarding, fraud and deceit. ${ }^{21}$ In Canada, some of the debate is still stubbornly focused on whether we have, indeed, a right to privacy at all in situations not involving the criminal law." As a result, some commentators have concluded that if privacy is not dead, it "is probably best described as alive, but on life support."23

The purpose of this article is to review and critique the existing conceptions of privacy. In Part II, I summarize both the prevailing conceptions of privacy and the criticisms that have been levelled against each. The current conceptions - six of which have generally been

Jeffrey H. Reiman, "Privacy, Intimacy, and Personhood" (1976) 6 Philosophy and Public Affairs 26. Richard B. Parker, "A Definition of Privacy" (1974) 27 Rutgers L. Rev. 275.

Jeflrey H. Reiman, "Driving to the Panopticon: A Philosuphical Exploration of the Risks to Privacy Posed by the Highway Technology of the Future" (1995) 11 Santa Clana Compuler \& High Tech. L.J. 27 [Reiman, "Driving to the Panopticon"].

Jed Rubenfeld, "The Right to Privacy" (1989) 102 Harv. L. Rev. 737.

Richard S. Murphy, "Property Rights in Personal Information: An Economic Defense of Privacy” (1996) 84 Gco. L.J. 2381.

Elizabeth M. Schneider, "The Violence of Privacy" (1991) 23 Conn. L. Rev. 973. See also Reva B. Siegel, "'The Rule of Love': Wife Beating as Prerogative and Privacy" (1996) 105 Yale L.J. 2117 , where she states that a husband's right to punish his wife - known as chastisement - was permitted so that courts would not have to interfere with "marital privacy."

Richard A. Posner, "John A. Sibley Lecture: The Right to Privacy" (1978) 12 Ga. L. Rev. 393. See Murphy, supra note 19; W.A. Parent, "Privacy, Morality, and the Law" (1983) 12 Philosophy and Public Affairs 269 at 277, where he states that, in Posner's view, the motivation of individual privacy was simply to "hide discreditable facts about themselves from luture employers who are entitled to this information."

2 Craig, supra note 4 . This is a point that I consider moot for several reasons. First, most jurisdictions in Canada have, in some fashion, legislated a privacy right. In such cases, the question is whether the facts establish that the statutory tont is engaged. Sce e.g. s. 60 of the Personal information Protection Act, S.A. 2003, c. P-6.5. Second, our courts are reluctant to strike out novel claims. For example, in Cooper 1. Hobart, [2001] 3 S.C.R. 537, 2001 SCC 79 and its companion case of Edwards v. Low Society of Upper Canada, [2001] 3 S.C.R. 562, 2001 SCC 80, the Supreme Court of Canada reviewed the proximily or neighbourhood principle established in Donoghwe (or McAlister) v. Stevenson, [1932] All E.R. Rep. I (H.L.) and in Anns v. Merton London Borough Council, (1977) All E.R. 492 (H.L.), and emphasized at paras. 23 and 25 that although there are various categories in which proximity has historically been recognized, those calegories are not closed, thus evidencing judicial reluclance to strike out novel claims, which presumably will include privacy claims. Third, privacy considerations are sprinkled throughout our Charter jurisprudence. As the common law is to be informed by our Charter values (see Dickason v. University of Alberta, [1992] 2 S.C.R. I 103 and Vriend v. Alberta, [1998] I S.C.R. 493), it is reasonable to conclude that our notions of privacy - as articulated in our Charter jurisprudence - will find a voice in the common law where needed.

Murphy, supra note 19 at 2388. See Irwin R. Kramer, "The Birth of Privacy Law: A Century Since Warren and Brandeis" (1990) 39 Cath. Univ. L. Rev. 703, where he observes at 723 that cases have overwhelmingly favoured the press and claims of privilege and qualilied privilege as to "virtually swallow the lort" (quoting Harry Kalven, Jr., "Privacy in Turt Law - Were Warren and Brandeis Wrong?" (1966) 31 Law \& Contemp. Probs. 326 at 336). Kramer continues on the same page:

Afler examining what she believes are insurnountable constitutional problems, Professor Zimmerman could not reconcilc Warren and Brandeis' views with existing first amendment rights and urged courts to abandon the tort of invasion of privacy: "[A]ner nearly a century of experience, ... it is probably time to admit defeat, give up the efforts at resuscitation, and lay the noble experiment in the instant creation of common law to a well-deserved rest" (citing Diane $L$. Zimmerman, "Requiem for a Heavyweight: A Farewell to Warren and Brandeis's Privacy Tort" (1983) 68 Comell L. Rev. 291 at 365). 
advocated - all have some intuitive appeal. Each can be used to rationalize some, but not all, of the myriad of ways that privacy comes under scrutiny in modern life.

In Part III, in addition to the criticisms levelled against each conception by proponents of other conceptions, I advance two additional criticisms, applicable to all, which I contend ultimately explain their inadequacy. First, the conceptions all suffer from intuitionism as regards what makes things private. They approach the question by asking us all to imagine horrible or nightmarish invasions of privacy. If we do not all share what is intuitively horrible or nightmarish, then the conception must falter. Second, the current conceptions are invariably based on a misconception of liberty as a form of licence where individuals are free to do as they please according to their own lights. As such, privacy finds itself in constant tension with other liberties. This is a conflict which, at least in the U.S., privacy usually loses.

In Part IV, accepting as I do the argument that the current conceptions of privacy do not adequately explain privacy in daily life, I explore two alternatives that have been advanced for privacy. First, one could remain within the existing paradigm but evaluate privacy cases against the conceptions working together, not in isolation. Some scholars have done precisely this and, indeed, such an approach appears to be evident in the Canadian judiciary. This approach leaves unanswered, unfortunately, the question of whether there is, indeed, a core value of privacy that all of the standing conceptions attempt to answer.

Another approach has been to abandon the search for a core value and instead approach privacy on a case-by-case basis. That is, one could accept that privacy has no inherent value of its own and merely serves other objectives. Such an approach, however, seems inconsistent with most jurisprudence, which recognizes privacy as a fundamental right worthy of constitutional protection in its own right.

In the conclusion, I summarize the state of privacy thus far and suggest, as another alternative for privacy, that it may be appropriate to change the existing paradigm against which privacy is evaluated. A new paradigm would approach privacy as an equality issue, not a liberty issuc. There is, 1 conclude, no merit in continuing to debate what liberties "action verbs" - privacy should protect unless we can first be satisfied that individuals have meaningful equality. ${ }^{24}$ Keeping things private does not, then, facilitate our liberty but rather it ensures our equality.

One might wonder whether anything is to be served by revisiting how privacy should be conceptualized. Ronald Dworkin, for example, notes that these sorts of exercises are of fundamental importance:

These are not puzzles for the cupboard, to be taken down on rainy days for fun. They are sources of continuing cmbarrassment, and they nag at our altention... Suppose a "novel right-of-privacy" case comes to court, and there is no statute or precedent claimed by the plaintifr. What role in the court s decision should be played by the fact that most people in the community think that privale individuals are "morally" entitled 
to that particular privacy? ... Conceptual puzzles about "the law" and "Icgal obligation" become acute when a court is confronted with a problem like this. ${ }^{25}$

It is to this task that 1 now lum.

\section{Current Conceptions of Privacy}

It is generally accepted that there are six conceptions of privacy that are currently championed. Privacy is seen as: (1) the right to be let alone; (2) the limited access to the self (autonomy); (3) secrecy and the concealment of discreditable information; (4) control over personal information; (5) creation of self/personhood and preservation of one's dignity; and (6) promoting intimacy and relationships..$^{26}$ Many of the conceptions overlap with each other and, as will be developed below, some scholars have abandoned a search for a single conception in favour of a combination of several that, in their view, explains privacy. Each will be considered in turn along with some criticisms specific to each conception. General criticisms - those that apply to them all - will be considered in the next section.

\section{A. The Right to be Let Alone}

This conceptualization of privacy dates back to 1890 , when two young lawyers penned a famous plea to have recognized a right to privacy at common law. ${ }^{27}$ Although no one is quite sure what moved Samuel D. Warren and Louis D. Brandeis to write, ${ }^{28}$ one can be sure that part of their motivation was to ensure that privacy was seen as a free-standing right worthy of protection in its own right and not derivative of some other more recognizable cause of action that required judges, then and in the future, to resort to legal fictions if predisposed to protect privacy. ${ }^{29}$ Warren and Brandeis simply argued, as a rights-based theorist would, ${ }^{30}$ that precedential cases, though not specifically referring to privacy,

Ronald Dworkin, Taking Rights Seriously (Cambridge, Mass.: Harvand University Press, 1977) at 14-15. Daniel J. Solove, "Conceptualizing Privacy" (2002)90 Cal. L. Rev. 1087. I do not take greal exception with Solove's characterizations of the prevailing conceptions since they appear to be supported by the literature on this subject. I say that with a number of qualifications, however. First, and most importantly, the characterizations do not affect my thesis one way or another. They are all based, in my view, on the commonly held - but erroneous - concepr of privacy as a liberty (as opposed to equality) interest. This forms the basis of my contention that all of the conceptions have proven unworkable even though, when considered separately, they each possess some intuitive appeal. Second, the theorics do not fit neatly into any one eategory and I doubt whether tle authors would necessarily agree with Solove's assignment of them subscribing to one conception as opposed to another. For example, Charles Fried defines privacy as "control over knowledge about oneself" ("Privacy" (1968) 77 Yale L.J 475 at 483). By the same token, however, Fried contends at 484 that "privacy is the necessary context for relationships which we would hardly be human if we had to do without - the relationships of love, friendship and trust." Is this a conception of privacy as control over information or promoting intimacy and relationships? This is simply one example where scholars use language that seems to overlap with other conceptions.

2* Sec, for example, Kramer, supra note 23 at 709 where legend, subsequently discredited, was that Warren, himself and his lamily being part of Boston's social elitc, became infurialed with the press having a lietd day on his daughter's wedding and so penned the Law Review article. Implied contract or breach of confidence where the "invasion" is between strangers, for example. Rights-based in the sense that one accepts that rights are inherent to the individual and are not dependent upon some extemal foree: "[T)hey are not the product of any legislation, or convention, or hypothetical contract" they are not "Igifts from] God, or an ancient ritual, or a national sport" (Dworkin, supra note 
nevertheless contained "privacy principles" 31 that could be applied independent of any property or other recognizable cause of action. ${ }^{32}$ The right to privacy envisioned by the article is prefaced on a distinct right to liberty - the right to be let alone. ${ }^{33}$

Warren and Brandeis argued that privacy is a right not dependent on "the interposition of the legislature," an "inviolate personality":

These considerations lead to the conclusion that the prolection afrorded to thoughts, sentiments, and emotions, expressed through the medium of writing or of the arts, so far as it consists in preventing publication, is merely an instance of the enforcement of the more general right of the individual to be let alone. It is like the right not to be assaulted or beaten, the right not to be imprisoned, the right not to be maliciously prosecuted, the right not to be defamed. In each of these rights, as indeed in all other rights recognized by the law, there inheres the quality of being owned or possessed - and (as that is the distinguishing attribule of property) there muy be some propriety in speaking of those rights as property. But, obviously, they hear little resemblance to what is ondinarily comprehended under thut term. The principle which protects personal writings and all other personal productions, not against thetl and physical appropriation, but against publication in any form, is in reality not the principle of private property, but that of an inviolate personality. ${ }^{35}$

Although this view has attracted significant scholarly interest throughout the twentieth century, ${ }^{36}$ it suffers from numerous difficulties. First, the underlying principle of privacy it promotes - that of "inviolate personality" - is not defined:

The formulation of privacy as the right to be let alone merely describes an attribute of privacy. Understanding privacy as being let alone fails to provide much guidance about how privacy should be valued vis-d-vis other interests, such as tree speech, effective law enforeement, and other important values. Being let alone does

Brandeis and Warren's famous argument about the right to privacy is a dramatic illusiration [of the point that precedent can be used to have a new principle striking out on a different line): they argued that this right was not unknown lo the law but was, on the contrary, demonstrated by a wide variety of decisions, in spite of the tact that the judges who decided these cases mentioned no such right [footnotes omitted].

Warren \& Brandeis, supra note 27 at 213: "The principle which protects personal writings and any other productions of the intellect or of the emotions, is the right to privacy, and the law has no new principle to formulate when it extends this protection to the personal appearance, sayings, acts, and to personal relation, domestic or otherwise."

Nole, however, that Warren \& Brandeis (ibid.) did not take credit for this phrase, crediting instead in note 4 at 195, Judge Cooley from T. Cooley, A Treatise on the Lav of Toris, $2 \mathrm{~d}$ ed. (1888) at 29. Even more interesting is that Coolcy himself used this term to encompass the individual's right to be free from physical attack, not any inchoatc, inarticulate right like privacy - see Kramer, supva note 23. Warren \& Brandeis, supra note 27 at 195.

Ibid. al 205.

Richard C. Turkington, "Legacy of the Warren and Brandeis Article: The Emerging Uneneumbered Constitutional Right to Informational Privacy" (1990) 10 N. III. U.L. Rev. 479) at $481-82$ where he states: "[T]he article has acquired legendary status in the realm of legal scholarship. It is likely that The Right to Privacy has had as much impact on the development of law as any single publication in legal periodicals. It is certainly one of the most commented upon and cited articles in the history of our legal system." Sec also Kramer, supra note 23. 
not inform us about the matters in which we should be let alune. Warren and Brandeis did speak of "inviolate personality", which could be viewed as describing the content of the private sphere, but this phrase is vague, and the authors failed to elaborale."

Second, the conception of privacy as the "right to be let alone" has, generally, been applied in situations involving state interference. It forms the basis in both Canada and the U.S. for many search and seizure cases in the criminal law context. It has also been used to justify a woman's right to an abortion ${ }^{3 \mathrm{~K}}$ or an unmarried couple's right to contraceptives ${ }^{39}$ in the U.S.

This conception is clearly inadequate where state interference is not the action complained of ${ }^{40}$ It is much too narrow, since it ignores the role - more prevalent today than in the past - that private actors play in the realm of privacy. In many situations that we now find ourselves faced with - particularly as a result of technological advancements in the collection, use and dissemination of personal information - it is becoming increasingly common for individuals to demand more, not less, state intervention on their behalf."

It is simultaneously too broad, as any form of invasion by the state would be prohibited under this conception. At its core is a concern that the individual not be denied liberty. ${ }^{42}$ Clearly, however, the state's obligations to ensure basic security and certain property rights for its citizens outweighs any unfettered right of individuals to do as they please. For these reasons, other conceptions of privacy have been advanced.

Solove, supra note 26 at $1101-102$.

Roe v. Wade, 410 U.S. 113 (1973).

Griswold v: Comnecticul, 381 U.S. 479 (1965) [Griswold] (which held as unconstitutional a statute criminalizing contraceptives for married couples). In Eisensteuth. Sheriffv. Baird, 405 U.S. 438 (1972) [Eisenstadt], Griswold was extended to the use of contraceptives by unmarried couples. Lois Shepherd, "Looking Forward with the Right of Privacy" (2000) 49 U. Kan. L. Rev. 25I at 264: As carly as Griswold it was apparent that privacy in the sense of a zone of behaviour not for public view did not completely describe the protections the Court wished to recognize for individuals against the state. While there was cerlainly an appeal to such a sense of privacy by reference to the marital bedroom and analogy to the Fourth Amendment's prohibition against unwarranted search and scizure, it would soon break down when we left the home, for example, to buy contraceptives [emphasis in original, footnotes omitted]. Which likely explains the explosion in information privacy statutes across all jurisdictions. Posner would take a more skeptical, but similar, view of the right to be let alone (supra note 21 ut 400 ) (footnotes
omitted):

It is no answer that such individuals have the "right to be let alone." Very few people want to be let alone. They want to manipulate the world around them by selective disclosure of thets about thenselves. Why should others be asked to take their self-serving claims at lace value and be prevented from obluining the information necessary to verify or disprove these claims'? 


\section{B. THE LIMITED ACCESS TO THE SELF (AUTONOMY)}

This conception of privacy requires "a zone of relative insulation from outside scrutiny and interference - a field of operation within which to engage in the conscious construction of self." ${ }^{, 43}$ Under this conception, we desire privacy

out of a sincere conviction that there are certain facts atout us which other people, particularly strangers and casual acquaintances, are not entitled to know ... but instead [we] are to be respected as autonomous. independent beings with unique aims to lulfill."

This conception emphasizes that privacy gives individuals "the opportunity to experiment with self-definition in private, and (if one desires) to keep distinct social, commercial, and political associations separate from one another.",

Ruth Gavison would be considered a proponent of this conception. ${ }^{\text {th }}$ In her vicw, there are three elements present in every legitimate privacy claim: secrecy, "the extent to which an individual is known; [anonymity], the extent to which an individual is the subject of attention; [and solitude], the extent to which others have physical access to an individual." $\$$ ? An intrusion must violate all three, simultaneously, to merit being labelled an invasion of privacy. $^{48}$

This conception, like the right to be let alone, suffers from being overly broad. Surely not all information about ourselves, however innocuous and whatever its source, is truly "private." Access to us occurs, in some form, many times a day without our knowledge. We are frequently overheard or seen saying or doing things in our daily lives without ever feeling that our privacy has somehow been invaded. One would surmise that only access to specific dimensions of ourselves or to particular matters or information would be worthy enough to attract privacy. ${ }^{40}$

Further, this conception links, again, privacy to liberty. This is exemplified by Lois Shepherd who, when adopting a similar conception of privacy as autonomy, states:

Julie E. Cohen, "Examined Lives: Inlomational Privacy and the Subject As Object" (2000) 52 Stan. L. Rev. 1373 at 1424. (2003) 101 Mich. L. Rev. 2163 at 2179. our coneern over our accessibility to others: the extent to which we are known to others, the extent to which others have physical access to us, and the exlent to whicli we are the subject of others "attention." Ibid. at n. 40.

t* bid. Accordingly, for example, the following could not properly invoke privacy, even though privacy is invariably asserted in all such clains: exposure to unpleasint noise, smells and sights, since solitude is missing: prohibitions of such conduct such as abortions, use of contraceptives and "unnatural" sexual intercourse; insulting, harassing or persecuting behaviour; presenting individuals in a "lalse light": unsolicited mail and unwanted phone calls; regulation of the way familial obligations should be discharged; and commercial exploitation. 
Under my analysis, at the heart of liberty is the opportunity to find meaning in our lives. This is why we value liberty. This thesis looks to what effect certain denials of liberty, such as the liberty to choose one's spouse or romantic partner, or the liberty to have or not to have children, have on the meaning people find in their lives. ${ }^{50}$

Here, too, does this conception suffer from being too broad. It is naive to assume that individuals share universal beliefs about which liberties are valuable, and therefore which matters are "private." The conception's coherence thus breaks down at this point. The conception carries the same albatross that other conceptions based on liberty as a form of licence do. Individual liberties may, and often do, conflict. This conception offers no guidance for balancing competing liberty interests, and therefore, which privacy interests are more important than others.

In addition, the requirement of solitude is also too narrow. It is somewhat of an oxymoron to be concerned about privacy for someone alone who has absolute solitude. Something more must be involved.

\section{SECRECY/CONCEALMENT OF DISCREdITABLE INFORMATION}

The leading proponent of this conception of privacy is an American judge, Richard Posner, who views privacy as an individual's "right to conceal material facts about themselves." 51 Posner views privacy as a form of self-interested economic behaviour, concealing true but harmful facts about oneself for one's own gain:

Much of the demand for privacy, however, concerns discreditable information, oflen information concerning past or present criminal activity or moral conduct at variance with a person's professed moral standards. And often the motive for concealment is ... to mislead those with whom he transacts. Other private information that people wish to conceal, while not strictly discreditable, would if revealed correct misapprehensions that the individual is trying to exploit, as when a worker conceals a serious health problem from his employer or a prospective husband conceals his sterility from his fiancée. $\$ 2$

Under this economic conception of privacy, it is simply inefficient that law should allow privacy to allow anything less than full disclosure:

An analogy to the world of commerce may help to explain why people should not - on economic grounds, in any event - have a right to conceal material faets about themselves. We think it wrong (and inefficient) that the law should permit a seller in hawking his wares to make false or incomplete representations as to their quality. But people "sell" themselves as well as their goods. They profess high standards of behaviour in order to induce others to engage in social or business dealings with them from which they derive an advantage but at the same time they conceal some of the facts that these acquaintances would find useful in forming an accurate picture of their character. ${ }^{53}$ 
Quite clearly this is a very restrictive - and cynical - conception of privacy. Under this conception, individual privacy would be eliminated for the sake of societal efficiency. If one agrees with this conception, then one must also reject privacy as a concept, that it has any intrinsic value as an important moral and political idea. Similar arguments - all in the name of efficiency - could be made to eliminate affirmative action or other policies that seek to ameliorate the conditions which historically disadvantaged groups of people have suffered. ${ }^{\text {s.4 }}$ Yet whoever seeks to make such an argument faces an unpalatable argument and a hostile reception. Can one credibly make the argument that nothing is private? I would think not but, in any event, it is a proposition to which I cannot subscribe.

This conception is also too narrow by focusing only on discreditable facts, which by its nature, creates a sort of perjorative air to the process. Not all information about an individual is discreditable or misleading. The books we read, the products we buy, the people we associate with are not necessarily unsavoury but we nonetheless view them as private matters. Nor do all of the activities which we assume to be private occur in the privacy of our homes (with whom we associate for example). ${ }^{\text {ss }}$ So the conception is too narrow on this score as well.

Posner responds to this latter criticism by suggesting that it is not only discreditable facts that individuals use privacy to conceal. Individuals also use privacy selectively in order to mislead. They do so for two reasons. ${ }^{56}$ First, true facts are selectively revealed in order to create different perceptions that people have about them. My friends have a much different perception about me than does my boss even though I have tried to deceive neither. Second, people are never reticent about revealing facts that show themselves in a favourable light. "Reticence comes into play when one is speaking to people - friends, relatives, acquaintances, business associates - who might use information about him to gain an advantage in some business or social transaction with him. Reticence is generally a means rather than an end." ${ }^{\text {s? }}$

Posner's response fails to consider the importance that an individual's control over information plays in privacy. Some private information we willingly disclose, but we nonetheless expect to maintain some control over the information. ${ }^{\mathrm{s}}$ Many claims of privilege would also fall under this rubric. ${ }^{39}$ Full disclosure of our information to our doctor or lawyer is necessary to ensure we get adequate medical treatment or legal advice, as the case may be. In such cases, is it reasonable to assume that we have, by our voluntary disclosure to our

A point similarly made by Ronald Dworkin when discussing different conceptions of equality in "What is Equality? Part 3: The Place of Liberty" (1987) 73 lowa L. Rev. 1. Solove, supra note 26 . Similarly, at 1153 he states:

Although many disruptions of privacy practices involve the disclosure of secrets, much of the information collected about individuals in databases consists of day-to-day, oflen nonsecret information such as name, address, phone number, race, gender, birth date, and so on. Trying to fit the problem into the conception of privacy as secrecy will not illuminate the problem very well: in fact, important aspects of the problem will be ignored or marginalized. knows the delight that people take in talking about themselves to complete strangers."

Solove characterizes this as selective disclosure - "criticizing a boss to a coworker does not mean that the employee desires that her boss know her comments" (stpra note 26 at II08), 
doctor or lawyer, abandoned our interest in preventing our trusted advisors from further disclosing our personal information? Perhaps, but perhaps that interest is not a "privacy" interest except under the broadest conceptions of privacy. ${ }^{60}$

Further, it is not simply the content of disclosed information that portrays an individual in an unfavourable or favourable light. Often $i t$ is the contex/ and the relationship between various bits of information that determine how one is perceived. Technology allows the collection, use and dissemination of personal information to occur effortlessly and, often, without the knowledge of the individual. Accordingly, if individuals cannot correct the information - either because they do not know that information about them has been disclosed or because they do not have the ability or means by which to do so - then Posner's economically efficient world of perfect disclosure is not feasible. Accordingly, some privacy advocates (most notably Charles Fried) would shift the privacy battleground to one of controlling the extent to which personal information is used. It is to that conception that I now turn.

\section{Control over Personal Information}

Under this conception, privacy is "the claim of individuals, groups, or institutions to determine for themselves when, how, and to what extent information about them is communicated to others." that the notion that privacy is related to secrecy - to limiting the knowledge of others about oneself - must be refined. Privacy is not simply an absence of information about us in the minds of others; rather, it is the "control over knowledge about oneself."

As noted above, control over personal information appears to be at the heart of claims of privilege. Fried states:

An excellent, very different sort of example ol a contingent, symbolic recognition of an area of privacy as an expression of respect for personal integrity is the privilege against self-incrimination and the associated doctrines denying officials the power to compel other kinds of information without some explicit warrant. By according the privilege as fully as it does, our society aflims the extreme value of the individual's control over information about himself. To be sure, prying into a man's personal allitirs by asking questions of others or by observing him is not prevented by the privilege. Rather it is the point of the privilege that a man cannot be foreed to make public infirmution about himself. 'Thereby his sense of control over what others know of him is significantly enhanced, even if other sources of the same information exist. Without his cooperation. the other sources are necessarily incomplete, since he himself is the only ineluctable wituess to his own

Perhaps any "reversionary" interest is not based on some strained notion of privacy but on some other currently recognized form of action such as breach of trust or centract, for example. Altemalively, perhaps the effect of the diselosure determines whether privacy is engaged. I will develop this alternative in a subsequent essay where I contend that, at its essence, privacy is engaged where the disclosure will tend to have a discriminatory effect - objectively determined - on an individual. Solove, supra note 26 at $1109-10$. Firied, supra nole 26. See also Jeffrey Rosen, "The Purposes of Privacy: A Response" (2001) 89 Geo. L.J. 2117.

-3 Iricd, ihid. at 483. 
present lile, public or private, intemal or manilest. And in formation about himself which others have to give out is in one sense information over which he hals already relinquished control. ${ }^{\text {th }}$

One can readily see the similarities between this conception and others including limited access and secrecy. As such, it suffers from the same sorts of criticisms. First, there are problems defining its terms. What "information" is covered? Certainly, it cannot be all information whatever its source. If so, the conception would be too broad. Perhaps it is simply intimate information. But, in that event, it would be too narrow as other information that we would not normally characterize as "intimate" we would still want protected (financial information, salary, job description or title to name a few examples). Further, by focusing on information, the conception has been criticized for excluding those aspects of privacy that are not informational, "such as the right to make certain fundamental decisions about one's body, reproduction, or rearing of one's children"65 or to disruptions of one's peace of mind, such as noises or smells. ${ }^{\text {tho }}$

Also, what is meant by "control"? If" control" means ownership of the information, then the conception may fit in some contexts, but not others. For example, who "owns" the health information in a patient's chart - the patient to whom the information relates or the health care provider who creates the chart? ${ }^{67}$ Who owns the information that a person was seen walking into an abortion clinic - the observer or the participant? Or taken further, who owns the information between two partners who collectively decide to have an abortion the mother (who undergoes the procedure) or the father (who may have participated in the decision)? What if the mother thinks this is private but the father does not?

These issues highlight the difficulty posed by information that is capable of being simultaneously possessed by a number of people - associations, for example. ${ }^{6 *}$ Who controls the information in these cases? These issues also highlight the difficulty with the commodification of information. Solove states:

[T]here are problems with viewing personal information as equivalent to any other commodity. Personal information is often formed in relationships with others, with all parties to that relationship having some claim to that information. For cxample, individuals are not the lone creators of their web-browsing inlormation, for most of that information is crealed from the interaction between the user and websites. Often. the market value of information is not created exclusively by the labor of the individual to whom it

Ibid. at 488 .

Solove, supra note 26 at 11 10. But should these fundamental decisions invoke privacy? There are lwo distinct aspects of these types of decisions. There is, first, the ability or liberty to make the decision itself. Then comes the consequences that flow from the decision, including who might have knowledge of the decision taken. One would expect that "privacy" would be invoked for the second aspect. but it does not necessarily follow in my view that privacy should, or needs to be, invoked for the first aspect of the decision. The questions are entirely separale - can I do it" followed by. who knows that I did it? Ibid. at II 15: "Privacy ... can be invaded even if nobody else knows something new about a person. such as being forced to hear propaganda, by being manipulaled by subliminul advertisements. or by being disnupted by a nuisance that thwarts one's ability to think or read" [footnoles omitted]. McInerney v. Moc.Donuld. [1942] 2 S.C.R. 138 [Mc/merney] suggests the latter, but a patient nevertheless retains a right of aceess to his or her chart. within the minds of millions. This is why intellectual property law protects particular tangible expressions of ideas rather than the underlying ideas themselves." 
relales but in part by the third party that compiles the information. For example, the value of personal information for advertisers and marketers emerges in part from their consolidation and categorization of that information. ${ }^{69}$

Control over personal information, as a conception of privacy, does not adequately address these issues.

\title{
E. Creation of Self/Personhood and the Preservation of One's Dignity
}

Similar to privacy as autonomy, the personhood conception of privacy is defended on the grounds that it protects an individual's self-identity, that it respects "those attributes [of an individual which are] ... irreducible in [his] selfhood." ${ }^{30}$ Others have described this conception variously as a protection against conduct that is "an affront to personal dignity [and an] ... assault on human personality [to protection of] ... the individual's interest in becoming, being, and remaining a person." It is a conception of privacy that has, at its core, the individual's right to experiment and make choices in an effort to define himself. Without privacy, it is argued, individuals inevitably bend to the "pressures to conform, ridicule, punishment, unfavourable decisions, and other forms of hostile reaction." "In that case, we are less likely to experiment and make choices, even bad ones: in such an environment, "[the observed person] is fixed as something - with limited probabilities rather than infinite, indeterminate possibilities."73

Edward J. Bloustein, an advocate of this conception, summarizes this matter as follows:

\begin{abstract}
The man who is compelled to live every minute of his life among others and whose every need, thought. desire, fancy or gratilication is subject to public serutiny, has been deprived of his individuality and human dignity. Such an individual merges with the mass. His opinions, being public, tend never to be different; his aspirations, being known, tend always to be conventionally accepted ones; his feelings, being openly exhibited, tend to lose their quality of unique personal warmth and to become the feelings of every man. Such a being, although sentient, is fungible; he is not an individual. ${ }^{74}$
\end{abstract}

The argument continues that to become the sort of independent, creative people that society hopes for, individuals need - by trial and error - experience in formulating their own judgments and in acting upon those judgments. Privacy provides the setting in which individuals can obtain that experience. ${ }^{73}$ Without the chance to experiment in an effort to

Ibid. [footnotes omitted].

Rubenfeld, supra note 18 at 753 , cited in Shepherd, supra note 40 at 268.

Solove, supra nole 26 at 1116 [footnoles omitted].

Gavison, supra nole 46 at 448.

Stanley I. Benn. "Privacy, Freedom, and Respect for Persons," in J. Roland Pennock \& J.W. Chapman. eds.. Nomos XIII: Privacy (New York: Atherton Press, 197I) I at 7 [emphasis in original].

Edward J. Bloustein. "Privacy as an Aspect of Human Dignity: An Answer to Dean Prosser" (1964) 39 N.Y.U. L. Rev. 962 at 1003.

A contention disputed by Posner, supra note 21 at 407: "However, history does not teach that privacy is a precondition to creativity or individuality. These qualities have flourished in societies, including ancient Greece, Renaissance Italy, and Elizabethan England, that had much less privacy than we in the
United States have today." 
define ourselves, "we will become something different than we currently are, something less noble, less interesting, less worthy of respect." 76

Most agree that this conception is either a more sophisticated version of "the right to be let alone" conception, or more likely, a combination of the "right to be let alone" and the "autonomy" conception. Regardless, it has certainly been applied more as the former and, accordingly, suffers from the same criticisms, such as: the conception's notion of "dignity" is too broad: $; 7$ it ignores the role that private actors play in modern day privacy invasions: and it does not rise to the challenge when presented with competing liberties. ${ }^{77}$ With regards to the latter criticism, Shepherd notes that this conception creates obvious tension between a person's right to define himself and society's right to define itself. Shepherd uses the following example:

We can see this played out in the consideration of the right of individuals to engage in homosexual activily. The personhood thesis would presumably support the right of homosexuals to engage in homosexual activity because of the imporance to their self-identity of such conduct. Under the personhood thesis, communities could not legislate against such behaviour and therefore ceruld not maintain legal intolerance of homosexuals. The republican critique insists that the identity of individuals may be formed by and supported by inclusion in communities. If the principles underlying the personhood thesis are given full appreciation. then for would-be members of a community intolerant of homosexuals, self-identity is impermissibly infringed. The value-neutrality of the personhood thesis, which is its core - that individuals have a right to define themselves, even against the norms of socicty - is lost when it prevents the existence of communities intolerant of some identities. ${ }^{79}$

Leaving aside any comment that anti-discrimination advocates may make, this conception has certain appeal. Its concern about maintaining dignity hints at understanding of the real problem that, at least for me, privacy should address - equality. It perpetuates, however, the existing paradigm of privacy as a concept: that privacy is a liberty issue. It may suffice for the moment simply to repeat my view that all conceptions which have at their core a conception of privacy as a form of licence will suffer from the same sorts of tension illustrative in Shepherd's example. As will be developed below, I contend that all such

Reiman. "Driving to the Panopticon," supra note 17 at 40.

$" \quad$ See Post, supra nole I at $2092-93$ (quoting Jeffrey Rosen, The Umuamed Gaze: The Desiruction of Privacy in America (New York: Random House, 2000)):

To equate privacy with dignity is to ground privacy in social forms of respect that we owe each other as members of a common community. So understood, privacy presupposes persons who are socially embedded, whose identily and self-worth depend upon the performance of social norms, the violation of which constitutes "intrinsic" injury. In these respects, the conception of privacy as a form of dignity is in theoretical and practical tension with Rosen's observation that " $t$ ] the ideal of privacy ... insists that individuals should be allowed to define themselves" (ellipsis in original).

Posner contends that Bloustein's view simply interchanges "privacy" for "personal liberty," which is a hallmark of the right to be let alone (Richard A. Posner, "The 1978 James McCormick Mitchell Lecture: Privacy, Secrecy, and Reputation" (1979) 28 Buff. L. Rev. 1). Similurly, Solove stales that theories of privacy as personhood tell us why we value privacy (to protect individuality, dignily, and autonomy), but their usual focus on limiting statc intervention in our decisions often gives ton little attention to the privale sector... Therefore, beyond an account of where the state ought to leave individuals alone, personhood theories frequently fail to explain how personhood is to be protected (supra note 26 at 1118 ). 
conceptions cannot adequately resolve the tension and, therefore, do not provide a satisfactory conception of privacy.

\section{F. Promotion of Intimacy and Relationships}

\section{This conception of privacy}

recognizes that privacy is not just essential to individual sell-creation, but also to human relationships.... By locusing on the relationship-oriented value of privacy, the theory of privacy as intimacy attempts to detine what aspects of life we should be ahle to restrict access to, or what inlormation we should be able to control or keep secret. ${ }^{\text {xu }}$

\section{The privacy tort represents not}

"a value asserted by individuals against the demands of a curious and intrusive society." but a necessary aspect of relations with others. Rather than upholding the "interests of individuals against the demands of community." inlormation privacy creales rules that in some significant measure "constitute both individuals and community." The fashion by which privacy standards carry out this constitutive task is by confining personal information within boundaries that the standards normatively define. In Post's words, privacy's function is to develop "information territories." The establislıment of these "information preserves" is a eritical means for defining social and individual lite... The critical inquiry ... is whether the "reasonable person" would find certain invasions of privacy "highly offensive."

This conception, too, is generally seen as too broad: everything that is intimate may not be private and vice versa. ${ }^{82}$ For example, Solove states:

\footnotetext{
The conception of privacy as intimacy fials to capture the problem in this context because for the most part, databases do not invade or disrupt our intimate lives. Our names, addresses, types of ears we own, and so on are not intimate facts about our existence, certainly not equivalent to our deeply held secrets or carefully guarded diary entries. In cyberspace, most of our relationships are more like business transactions than intimate interpersonal relationships. ${ }^{83}$
}

Solove, supra note 26 at 1121.

Treanor \& Schwartz, supra note 45 at 2177.78, quoting Robert C. Post. "The Social lioundations of Privacy: Community and Self in the Common Law Tort" (1989) 77 Cal. L. Rev. 957 [footnotes onilted]. W.L. Weinstein, "The Private and the Free: A Conceptual Inquiry" in Pennock \& Chapman, eds., supro note 73 at 27: "Individuals not intimately reluted may nevertheless assert that their relation or activity is a private one in the sense that it is not the proper concem ol the community or some institution, such as the state, a church, or a business firm."

Solove. supra note 26 at 1 153-54. 


\section{A Critique uf THi. Current Conch.ptions}

\section{A. Summary of Standing Criticisms}

A general overview of the criticisms is in order. The criticisms contend that the conceptions are either too narrow or too broad in their application. Indeed, they are often both simultaneously.

The prevailing conceptions are too narrow by emphasizing state action in private activities and ignoring the impact that private actors have on privacy in a modern society (right to be let alone or dignity). They are also too narrow because they are confined to particular situations (autonomy) or particular types of information (discreditable facts or intimate information, for example) that ignore a broader interest that a person may have in subsequently controlling information that has voluntarily been disclosed.

They are also too broad. Many of the conceptions are overly expansive. Some situations require the state to intervene on its citizens' behalf, so it is difficult unequivocally to defend conceptions of privacy that require non-interference by the state (right to be let alone, dignity). For other conceptions, the type of information protected is overly broad by protecting all sorts of innocuous information or activities that we would not normally consider private. One would assume that only certain types of activities or information would attract privacy (autonomy, control over information). Finally, some conceptions (control over information, promoting relationships) fail to consider the difficulty posed by information that is capable of being simultaneously possessed by a number of people - who owns or controls the information in those cases?

\section{B. ANalysis of Standing Criticisms}

The criticisms have, at their core, two components. First, the conceptions sulfer from intuitionism. They offer an intuitive approach of what makes things "private." They assume, incorrectly in my view, that we approach privacy with a common understanding of the concept, or concepts, that the term "privacy" expresses. "Individual autonomy," "dignity" and "creation of self" are themselves concepts capable of different conceptions. Without consensus about the underlying concepts associated with each conception, none of the conceptions can provide a coherent theory of privacy.

Second, underlying the various conceptions of privacy is a concept of liberty which is itself flawed. "Liberty" is seen as a form of licence, protecting - in its most crude form an individual's right to do as he pleases. Privacy protects, under such a view, simply "action verbs" - to possess pornography, to associate with unsavoury causes or to make unpopular decisions. The deficiencies with such a view come into focus when competing liberty interests are at stake. Whose liberty interest prevails where you have a particular conception of a moral society, but I choose to live a lifestyle that you consider immoral? Privacy has been invoked to justify, or deny, these sorts of decisions.

Each of these criticisms will be considered in turn. 


\title{
1. INTUITIONISM
}

One significant difficulty with the prevailing conceptions of privacy is that they are all premised, in varying degrees, on an "intuitionist analysis." "Individual autonomy," "dignity," and "creation of self," to take a few examples, are themselves concepts capable of different conceptions. Intuitionist arguments presume universal conception of these vague concepts. If consensus does not exist, the conceptions will be exposed as incoherent failures. James Q. Whitman puts the matter thus:

\begin{abstract}
Overwhelmingly, privacy advocates rely on what moral philosophers call "intuitionist" arguments. In their crude form, these sorts of arguments suppose that human beings have a direct, intuitive grasp of right and wrong - an intuitive grasp that can guide us in our ordinary ethical decisionmaking. Privacy advocates evidently suppose the same thing. Thus, the typical privacy article rests its case precisely on an appeal to its reader's intuitions and anxictics about the evils of privacy violations. Imagine invasions of your privacy, the argument runs. Do they not seem like violations of your very personhood? Since violations of privacy seem intuitively horrible to everybody, the argument continues, safeguarding privacy must be a legal imperative, just as safeguarding property or contract is a legal imperative. Indeed, privacy matters so much to us that laws protecting it must be a basic element of human rights. ${ }^{84}$
\end{abstract}

One does not need to strain to find evidence of intuitive analysis lying at the heart of various conceptions. Shepherd, for example when describing elements of the personhood conception of privacy, states:

While it is true that the specific relationships or endeavours or pursuits that will be meaningful to each individual are unique to that individual, we probably have some general, rough consensus of the sorts of things that supply individuals with meaning - or at least the sorts of freedoms they need to search for them. ${ }^{85}$

Comments like these evidencing an intuitionist analysis are not unique to academic lawyers. Examples of intuitive analysis also exist in the judiciary. ${ }^{86}$

Janes Q. Whitman, "The Two Western Cultures of Privacy: Dignity Versus Liberty" (2004) I 13 Yale L.J. 1151 at IIS4 [footnotes omitted, emphasis added].

ss Shepherd, supra note 40 at 303 [emphasis added].

no None of our "informational privacy" cuses that have, to date, been considered on judicial review have approached the issue first by conceptualizing what privacy is generally before considering the statutory language used. Further, the prevailing trend is for the courts to not simply defer to the decisions of the Information and Privacy Commissioners - all of whom have superior expertise to that of the courts in matters involving privacy, which is one factor that bespeaks of a deferential standard of review. This raises the potential of adding another layer of intuitive analysis on the issue. I include the following cases as examples of this: Information Commissioner v. RCMP, supra note 8; Macdonell v. Quebec (Commission d'accés a l'information), supra note 7; Dagg, supra note 2; The University of Alberla v. Pylypiuk (2002), 310 A.R. 300, 2002 ABQB 22; Alberta v. Krushell (2003), 340 A.R. 227, 2002 ABQB 252: Jolm Doe v. Ontario (Information d Privacy Commissioner) (1993), 13 O.R. (3d) 767 (Gen. Div.); Onturio (Solicitor Gencral) v. Ontario (Assistumt Information and Privacy, Commissioner) (1993), 102 D.L.R. (4th) 602 (Ont. Gen. Div.) rev'd (1993), 107 D.L.R. (4th) 454 (Ont. C.A.); Ontario (Allorney General) v. Fineberg (1994), 19 O.R. (3d) 197 (Gen. Div.); Ontario (Workers' Compensartion Board) v. Ontario (Assistan Information \& Privacy Commissioner) (1999), 41 O.R. (3d) 464 (C.A.); Ontario (Freedom of Information \& Protection of Privacy Co-ordinator, Ministry of Finance) v. Ontario (Assistant Information \& Privacy Commission) (1997), 46 Admin. L.R. (2d) 115 (Ont. Gen. Div.); Walmsley v. Ontario (Allorney General) (1997), 34 O.R. (3d) 611 (C.A.); Fletcher Challenge Canada 
It is simply inconceivable that intuitive consensus is possible, nor is such an approach desirable. Whitman observes that "no matter how anxiety-inducing it may be to read these authors [who assume an intuitionist approach], their arguments only carry real weight if it is true that the intuitions they evoke are shared by all human beings." ${ }^{\circ 7}$ Since "intuitive commonality" is not possible, Whitman rejects all arguments based on intuitionism:

Indeed, it is a basic error to try to explain or justify any aspect of the law by appealing to our unmediated intuitions about what seems evil or horrible... Crude intuitionism is prelly much dead anong moral philosophers, and it ought to be dead in the law too... In liberal Western societies, law is regarded as a weapon of last resort, to be drawn only when authentically fundamentul values of society are at stake. This has a consequence that deserves to be stated over and over again: It is the very nature of being a member of a liberal society that one must live with many things that seem horrible. If the sort of arguments mounted by privacy advocates were valid. many things indeed would be forbidden.... [For privacy] [w]e cannot simply start by asking ourselves whether privacy violations are intuitively horrible or nightmarish. The job is harder than that. We have to identify the fundamental values that are at stake in the "privacy" question as it is understood in a given society. The task is not to realize the true universal values of "privacy" in every society. The law puts more limits on us than that: The law will not work as laws, unless it seems to people to embody the basic commitments of their society. ${ }^{\text {sx }}$

While I generally agree with Whitman's rejection of intuitionist analysis, he ignores the underlying problem with the approach. Intuitionist arguments presume abstract concepts back into the argument before consensus on these concepts is evident. As stated above, a conception can only approach coherence if, and when, reasonable people agree on the underlying concepts. Why quibble about what faimess dictates in any given situation, if we are unable to agree that fairness is a desirable objective in the first place? In the context of privacy, one would expect to see the conceptions falter if the underlying concept - privacy as liberty - is demonstrated to be deficient. This leads to my next criticism, addressed below.

\section{LIBERTY AS A FORM OF LICENCE}

A related criticism is that the current conceptions of privacy are invariably based on an underlying concept of privacy as a liberty interest which is itself flawed. They have, as their rallying point, a conception of liberty as a form of licence which finds "liberty," as a commodity, ${ }^{89}$ at odds with state interests. Numerous examples demonstrate that privacy, at least in the U.S., is primarily invoked to protect various liberty interests - "action" verbs

Lud. v. British Columbia (huformation \& Privacy Commissioner) (1996), 38 Admin. L.R. (2d) 230 (B.C.S.C.); Aquasomete Led. v. British Columbia (Information \& Privey Commissioner), [1999] 6 W.W.R. I (B.C.C.A.).

87 Whitman, supra note 84 at 1155.

93 Ibid. at 1220 [emphasis in original].

89 To use Dworkin's language, supra note 25. 
- from intrusions by the state." Privacy has been asserted to allow abortions, ${ }^{91}$ contraceptives for married ${ }^{92}$ and unmarried couples, ${ }^{93}$ interracial marriages, ${ }^{94}$ "unnatural" sexual activity" and the private possession of "obscene" material. ${ }^{96}$

Two consequences follow when liberty is conceived as a form of licence. Insofar as liberty is in competition with state interests, privacy is simply a negative form of liberty. Dworkin characterizes negative liberty as the absence of constraints placed upon an individual by the state:

Thave in mind the traditional definition of liberty as the absence of constraints placed by a government upon what a man might do if he wants to. Isaiah Berlin, in the most famous modem essay on liberly, put the matter this way: "The sense of freedom, in which 1 use this term, entails not simply the absence of frustration but the absence of obstacles to possible choices and activities - absence of obstructions on roads along which a man can decide to walk.' This conception of liberty as license is neutral amongst the various activities a man might pursuc, the various roads he might wish to walk."7

Liberty as a lorm of licence ignores the fact that privacy has both negative and positive aspects to it. As noted above, many of the conceptions are particularly vulnerable to criticism simply because they consider only the role that state interference plays and ignore the broader impact that private actors play in modern invasions of privacy. A coherent conception of privacy would seem to embrace state intervention in some cases, and state

Indeed, even scholars seem to concede that it is a conception of privacy that is liberty based, although they may not concede that the conception of liberty is in turn a form of licence. For example, Fried states: "Most obviously, privacy in its dimension of control over information is an aspect of personal liberty" (supra note 26 at 483 ). In a similar vein, Whitman states:

At its conceptual core, the American right to privacy still takes much the form that it took in the eighteenth century: It is the right to frecdom from intrusions by the state, especially in one's own home. The prime danger, from the American point of view, is that "the sanclity of [our] home[s]." in the words of a leading nineleenth-century Supreme Court opinion on privacy [Boyd $v$. Unifed Steres, 116 U.S. 616, (1886)], will be brenched by govermment actors. American anxicties thus focus comparutively little on the media. Inslead, they lend to be anxieties about maintuining a kind of privale sovercignty within our own walls (supra note 84 at $1161-62$ [fiotnoles omilted]).

Finally, while commenting on the right to be let alone, autonomy and promoting human relationships conceptions of privacy, Gavison noles that they are all based on liberty arguments:

Each of these arguments based on privacy's promotion of liberty shares a common ground: privacy permits individuals to do what they would not do without it for fear of an unpleasant or hostile reaction from others. This reaction may be anything from legal punishment or compulsory commitment to threats to dissolve an important relationship. The question arises, then, whether it is appropriate for privacy to permit individuals to escape responsibility for their actions, wishes, and opinions (supra note 46 at 451 ).

Roc' v: llade, supra note 38.

Cirisurold, supra note 39.

Risenstud, supra note 39.

Lowing v. Virginia, 388 U.S. 1 (1967).

Lawrence v. Texas, 539 U.S. 235 (2003), which dealt with sodomy.

Lowing v. Virginia, supra note 94.

Dworkin, supra note 25 at 267. 
silence in others. ${ }^{98}$ As mentioned previously, such a conception is not likely where liberty is viewed as a form of licence.

Second, if a form of licence, then liberty is not simply at odds with the state but often finds itself in competition with other liberty interests. 99 As such, some individual (or societal) liberty interest must take preference — and therefore importance — over a competing liberty interest. Dworkin, for example, describes the problem as follows:

Liberty as license is an indiscriminate concept because it does not distinguish among forms of behavior. Every prescriptive law diminishes a citizen's liberty as license: good laws, like laws prohibiting murder, diminish this liberty in the same way, and possibly 10 a greater degree, as bad laws, like laws prohibiting political speech. The question raised by any such law is not whether it attacks liberty, which it does, but whether the attack is justified by some competing value, like equality or safety or public amenity. If a social philosopher places a very high value on liberty as license, he may be understood as arguing for a lower relative value for these competing values. If he delends freedom of speech. for example, by some general argument in favour of license, then his argument also supports, at least pro tanto. freedom to form monopolies or smash storefront windows. ${ }^{100}$

In the context of privacy, this is tantamount to an acknowledgment that one privacy interest is more important than another privacy interest. This amounts to a zero sum gain. Further, when privacy competes with other liberty values, privacy claims do not generally succeed, at least in the U.S. This is particularly true where rights enumerated in the American Constitution such as right to freedom of the press or freedom of speech compete with nonenumerated rights such as privacy: ${ }^{101}$

[P]rivacy is not the only cherished American valuc. We also cherish inlotmation, and candour, and freedom of speech. We expect to be free to discover and discuss the secrets of our neighbours, celebritics, and public officials. We expect govermment to conduct its business publicly, even if that infringes the privacy of those caught up in the matter. Most of all, we expect the media to uncover the truth and report it - not merely the truth about government and public affairs, but the truth about people.

Solove, supra note 26 at 1120 notes the importance of positive liberty for privacy:

Without protection against rape, assuult, trespass, collection of personal information, and so on. we would have little privacy and scant space or security to engage in self-definition. To preserve people's ability to engage in self-definition, the stite must actively intervene to curtail the power of customs and noms that constrain freedom.

Just as academic lawyers concede that their conceptions are liberty-based, they also seem to acknowledge the challenge presented by competing liberties:

[As] is true for property or bodily security, the control over privacy must be limited by the rights of others. And as in the cases of properny and bodily security, so too with privacy the more one ventures into the outside, the more one pursues one's other interests with the aid of, in competition with, or even in the presence of others, the more one must risk invasions of privacy (Fried. supra note 26 at 486).

100 Dworkin, supra note 25 at 262.

101 Jesse A. Mudd. "Right to Privacy v. Freedom of Spech: A Review and Analysis of Aarmickiv. Verper" (2002) 41 Brandeis L.J. 179. See Murphy, supra note 19 at 2392 where he concludes:

The disclosure tort is not a complete dead letter: it is technically a viable cause of action in about thirty-five states, and occasionally plaintiffs win. But overall, it has fared poorly. One reason it has failed is that it is not conceived as a dispule about property rights in information, but rather as a battle between First Amendment values and an inchoate, elastic privacy "right." It is easy to sec why the First Amendment generally wins this battle [footnotes omitted]. 
The law protects these expectations too -- and when they collide with expectations of privacy, privacy almost always loses. ${ }^{102}$

Is it possible to conceptualize privacy in such a fashion that "true" privacy claims do not compete? ${ }^{103}$ If the standings conceptions of privacy are deficient, then what options does the modem privacy advocate have? Two alternatives have been suggested. It is to these that I now turn.

\section{Alternatives for Privacy}

The current conceptions of privacy are, quite simply, deficient. As the examples at the start of this essay suggest, this bold statement should not come as a surprise. Indeed, scholars, while championing their own conceptions, ably articulate why other conceptions are inadequate to explain the myriad of ways that privacy is affected in our daily lives. I am by no means the only — or first - writer to note this. Tom Gerety observed that privacy has "a protean capacity to be all things to all lawyers." thing that the various conceptions of privacy have in common is simply the privacy label. ${ }^{105}$

If the current conceptions do not work, then we are left with the several alternatives. First, we can, as some scholars have done, abandon the conceptions individually in favour of a consortium of conceptions working together. If no one conception is persuasive, perhaps a cluster of conceptions taken in concert will be more successful.

Alternatively, we can abandon the search for a core value of privacy in favour of a different conceptual framework. Solove does precisely this by abandoning the search for the essence of privacy in favour of a "pragmatic" approach to privacy which "focuses on the palpable consequences of ideas rather than on their correspondence to an ultimate reality." 100 In Solove's view, "there is no one answer [to privacy,] but a variety of answers depending on a variety of factors." 107

1 will consider these two alternatives in turn. ${ }^{10 x}$

David A. Anderson, "The Failure of American Privacy Law" in Basil S. Markesinis, ed., Protecling Privacy: The Clifford Chance Lectures. Volume Four (New York: Oxford University Press, 1999) 139 at 140 .

I contend that it is indeed possible, but not if we continue to conceive of privacy as liberty and to hold on to the standing conceptions thereol which view liberty as a form of licence. Tom Gerety, "Redefining P'rivacy" (1977) 12 Harv. C.R.-C.L.L. Rev. 233 at 234.

Solove, supra nole 26.

thid. at 1091 . This approach, Solove contends, "urges philosophers to become more enseonced in the problems of everyday life; adapts theory to respond to flux and change rather than seeking to isolate lixed and immutable general principles; and emphasizes the importance of the concrete, historical, and factual circumstances of life."

A third alternative is to change the existing paradigm against which privacy is evaluated. 


\section{A. Combine Current ConCePtions}

One can readily find evidence suggesting that several of the conceptions overlap. Indeed, often proponents of one conception of privacy seem to use terminology associated with another. In some cases, the overlapping appears to be innocent, almost as if by accident. For example, autonomy is often used in the same context as the creation of self or dignity, or alternatively, the right to be let alone is commonly cited in contexts where personhood or autonomy is the conception of privacy being advanced. One is often left, in such cases, wondering which conception of privacy is actually being championed.

One example of this latter approach is the "anti-totalitarian" conception of privacy advocated by Jed Rubenfeld. ${ }^{109}$ Under this view, the right of privacy prevents the state from occupying the totality of our lives: "The point is not to save for the individual an abstract and chimerical right of defining himself; the point is to prevent the state from taking over, or taking undue advantage of, those processes by which individuals are defined in order to produce overly standardized, functional citizens." 110 Shepherd has observed that, under this view: "Democracy, by definition, rejects totalitarian intrusions into people's lives because totalitarianism destroys the independent thinking nature of the population needed to sustain the democracy." "11

Without privacy rights or some other protection against totalitarianism, we will have, under this view, "a monolithic society created by government-imposed norms."112 That is, we will have state-created automatons. Rubenfeld seems to connect the right to be let alone conception with the personhood or autonomy conceptions of privacy. Which one is not clear. He complicates the conception further by drawing an additional distinction between an individual's right to define himself and society's right to define itself. However it is viewed, the right to be let alone appears to be fundamental to Rubenfeld's conception. As with other similar conceptions, this conception does not contemplate the role that non-state actors play in the privacy arena.

Alternatively, sometimes the overlap appears to be by design. Given the recognition that no one conception of privacy seems satisfactorily to address all privacy claims, some scholars have abandoned any single conception in favour of a combined conception. An attempt to conceptualize privacy by connecting three distinct concepts - control over information, dignity/personhood and autonomy - is one such attempt. ${ }^{113}$ Consider the following argument for privacy made by Jeffrey Rosen:

When private information is taken out of context, the only way to try to put the information in a broader context is to reveal more private information. This only increases the risk of misinterpretation because certain kinds of privale information can only be understood in a context of intimacy and should only be exposed under conditions of trust. This means that even if the revelation of more private information led to more understanding. it would nevertheless compound the injury of the initial exposure. That injury is an oflense

10 Rubenfeld, supra note 18.

$110 \quad$ bid. at 794.

III Shephend, supra note 40 at 275.

112 Ibid.

113 See Post, supra note 1 , where he reviews this recent conceptualization. 
against autunomy as well as dignity - against both the self-defined " $I$ " and the socially defined "me." The autonomy that the backstage area protects is not merely freedom from totalizing forms of state scrutiny but also freedom from overly intrusive forms of social scrutiny. Respecting the privacy of that backstage spares us the burden of justifying differences that no one in a liberal society should be foreed to submit to communal inspection and debate. ${ }^{1 / 4}$

Rosen's choice of terminology certainly seems to suggest he is advancing several conceptions of privacy at once.

This alternative does have some appeal. Although suffering from criticisms of being too broad, or too narrow, or both, the current conceptions considered in isolation seem to provide - at least superficially - the best explanation of privacy in some contexts. Certainly more "privacy" cases will be caught if the conceptions are considered cumulatively, rather than in isolation. The disadvantage with this approach is that it does not answer our original question: is there a common value inherent in all privacy cases? Unless a common denominator is articulated, combining conceptions simply perpetuates the piecemeal, haphazard approach to privacy that has marked the privacy landscape so far. Nor will it provide a satisfactory answer for the hard privacy cases as they occur. ${ }^{11}$

\section{l. Conceptions of Privacy and the Canadian Judiciary}

One does not need to strain to find evidence that the current conceptions of privacy have found a voice within the judiciary. I have previously highlighted some U.S. cases which have espoused various conceptions of privacy in support of their decisions. ${ }^{116}$ The current conceptions of privacy are also evident in Canadian jurisprudence. A small sampling of cases will suffice to make this point. ${ }^{117}$

It is perhaps not surprising that the "right to be let alone" conception of privacy is predominantly found in the context of the criminal law. Prohibitions against unreasonable search and seizure ${ }^{118}$ attempt to balance important, but competing, individual interests (such as privacy and de facto liberty) against state interests in crime detection and prevention.

Rosen, sippra nole 62 at 2118.

To borrow from Dworkin who applies his rights theory to a series of "hard" cases.

Scholars do nol, however, invariably agree on which conception of privacy governs in any given case. Many scholars suggest that the "right to be let alone" is the prevailing conception for cases involving abortion (Roe 1 . Wade, supra note 38), interracial marriages and the availability of contraceptives (Griswold and Eisenstadt, supra note 39). Solove, by contrast, characterizes these decisions as based on the personhood conception of privacy (supra note 26).

An exhaustive summary of Canadian cases is not required to make the point that the current conceptions of privacy do indeed form the basis for many of the judiciary's decisions involving privacy. I am simply arguing that the conception of privacy must evolve into privacy as an equality right. For an exhaustive review of Canadian jurisprudence, see Barbara A. Mclsaac, Rick Shields \& Kris Klein, eds., The Lan' of Privucy in Canuda, looseleaf (Toronto: Carswell, 2000).

Section 8 of the Canadian Charter, stupra note 10, states: "Everyone has the right to be secure against unreasonable search or seizurc." The Fourth Amendment of the United States Constitution provides: "The right of the people to be secure in their persons, houses, papers, and effects, against unreasonable searches and seizures, shall not be violated, and no Warrants shall issue, but upon probable cause, supported by Oath or affirmation, and particularly describing the place to be searched, and the persons or things to be seized." 
Hunter v. Southam Inc. is, of course, the seminal case illustrative of this conception. ${ }^{119}$ Paraphrasing Warren and Brandeis, Dickson J. (as he then was) characterized privacy as simply the "public's interest in being left alone by government." 120 In doing so, however, Dickson J. (as he then was) emphasized that s. 8 of the Charter protects "people, not places or things" - an attempt, no doubt, to distance the Canadian Court from the problems experienced in American jurisprudence that seems precccupied with the "sanctity of one's home."121

The "right to be let alone" conception is not the only conception of privacy that the Supreme Court of Canada has embraced, nor are the conceptions limited to consideration in criminal cases.

In Hill v. Church of Scientology of Toronto, ${ }^{122}$ which dealt with a Charter challenge to the common law tort of defamation, Cory J. reiterated the constitutional significance of the right to privacy emphasizing the "autonomy" conception of privacy. ${ }^{123}$

[1984] 2 S.C.R. 145 [Hunter]. The facts of this case are well known but bear repeating: Involved the constitutionality of s. $\mathrm{LO}(1)$ and $10(3)$ of the Combines Investigation Act, R.S.C. 1970, c. C-23 and specifically whether the broad search and seizure provisions were inconsistent with the right to be secure against unreasonable search and seizure. Pursuant to s. $10(1)$ of the Combines Imestigation $A C t$, the Director of Investigation and Research of the Combines Investigation Branch authorized several Combines Investigation officers to enter and examine documents and other things at a respondent's business premises in Edmonton "and clsewhere in Canada." The authorization was certified by a member of the Restrictive Trade Practices Commission pursuant to s. 10(3) of the $A$ et. The authorization was not. however, a judicial warrant.

120 Dickson J. (as he then was) states:

The guarantee of security from unreasonable search and seizurc only protects a reasonable expectation. This limitation on the right guaranteed by s. 8 , whether it is expressed negatively as freedom from "unreasonable" scarch and seizure, or positively as an entitlement to a "reasonable" expectation of privacy, indicates that an assessment must be made as to whether in a particular situation the public's interest in being left alone by government must give way to the government's interest in intruding on the individual's privacy in order to advance its goals, notably those of law enforcement (Hunter, ibid, at 159-60 [emphasis in original]).

131 A point echoed by La Forest J. in Dymen, (supra note 3 at 426-27)where he notes that, while having its historical roots in the right against unreasonable search and seizure, the right to be let alone simply in one's home is not sufficiently broad enough to address modem privacy concerns in the criminal law:

The lives of people in carlier times centred around the home and the significant obstacles built by the law against governmental intrusions on property were clearly seen by Coke to be for its occupant's "defence" and "repose"; see Semayne's Case (1604), 5 Co. Rep. 91 a, 77 E.R. 194, at p. $91 \mathrm{~b}$ and p. 195 respectively. Though rationalized in terms of property in the great case of Entick v. Carrington (1765), 19 St. Tr. 1029, 2 Wils. K.B. 275, 95 E.R. 807, the effect of the common law right against unreasonable searches and seizures was the protection of individual privacy. Viewed in this light, it should not be cause for surprise that a constitutionally enshrined right against unreasonable scarch and scizure should be construed in terms of that underlying purpose unrestrained now by the technical tools originally devised for securing that purpose. However that may be, this Court in Hunter v. Southam Inc. clearly held, in Diekson J.'s words, that the purpose of $\mathrm{s} .8$ "is ... to protect individuals from unjustified state intrusions upon their privacy" (supra, p. 160) and that it should be interpreted broadly to achicve that end, uninhibited by the historical accoutrements that gave it birth. 
In R. v. Plant ${ }^{124}$ and McInerney v. MacDonald, ${ }^{125}$ "control over information" is the primary conception of privacy being considered. In Plant, ${ }^{126}$ Sopinka J. emphasized that although a person may feel compelled to disclose information about himself, he may nevertheless have a reasonable expectation that the information shall remain confidential to the persons to whom, and restricted to the purposes for which, it is divulged. Such expectations must be constitutionally protected. ${ }^{127}$

Mclncrney was a civil suit involving privacy of medical records. While technically an access issue and not an invasion issue per se, Mclnerney demonstrated the judiciary's concern about an individual retaining some form of control over his or her personal information. Here a patient sought access to her medical records. Some but not all records were provided to her. ${ }^{128}$ In ordering the entire file - including the disputed reports - be provided to the patient, La Forest J. for the Court emphasized that an individual retains a "basic and continuing interest in what happens to [personal] information, and in controlling access to it." ${ }^{29}$ This interest continues even where the individual lacks any proprictary rights in the form of record.

I34 Supra note 11.

12: Stipra notc 67.

1:0 Plam (supra note 11) dealt with a search and seizure of the electric consumption records of a suspected drug dealer stored in the computer database of the utility company. The majority of the Supreme Court of Canada held that such records were not personal and confidential and, therefore, did not attract constitutional protection.

I:: Plant, ibid. Interestingly, however, Sopinka J. concluded that the electricity records do not attract constitutional protection. Compare his reasoning with that of McLachlin J. (as she then was) who, though ultimately agreeing with Sopinka J.'s result, nevertheless concluded that the records were indeed private, requiring the state to justify a warrantless search. She staled at 302-303:

The question in each case is whether the evidence discloses a reasonable expectation that the information will be kept in confidence and restricted to the purposes for which it is given. Although 1 find the case of electricity consumption records close to the line, I have concluded that the evidence here discloses a sufficient expectation of privacy to require the police to obtain a warrant before eliciting the information. I conclude that the information was not public, since there is no cvidence suggesting that this information was availuble to the public and the police obtained access only by reason of a special arrangement. The records are capable of telling much about one's personal lifestyle, such as how many people lived in the house and what sort of uctivities were probably taking place there. The records tell a story aboul what is happening inside a private dwelling, the most private of places. I think that a reasonable person looking at these facts would conclude that the records should be used only for the purpose for which they were made - the delivery and billing of electricity - and not divulged to strangers without proper legal authorization.

I disagree with my colleague's assertion that "[t]he computer records investigated in the case at bar while revealing the pattern of electricity consumption in the residence cannot reasonably be said to reveal intimate details of the appellant's life sinee electricity consumption reveals very little about the personal lifestyle or private decisions of the occupant of the residence" (p. 293). The very reason the police wanted these reconds was to learn about the appellant's personal lifestyle, i,c. the fact that he was growing marihuana. More generally, electricity consumption records may, as already noted, reveal how many people live in a house and much about what they do. While not as revealing as many types of records, they can disclose important personal information. 
Several cases have emphasized the personhood/dignity conception of privacy. Both $R$. $v$. $O^{\prime} C^{\prime}$ onnor $r^{130}$ and $M .(A$.$) v. Ryan { }^{131}$ involved production of medical and counselling records, but in entirely different contexts. ${ }^{132}$ In both cases, however, the Supreme Court of Canada emphasized the impact that the production of private medical records would have on the dignity of the complainants and plaintiff as the case may be. For example, L'Heureux-Dubé J. stated in Ryan:

Writing for the Court on this issuc, I concluded that the rights to individual libery and security of the person as enshrined in $\mathrm{s}$. 7 of the Churter encompassed a right to privacy. This linding was based on a number of developments in the jurisprudence of this Court. In its s. 7 jurisprudence, it has expressed great sympathy with the notion that liberty and security of the person involve privacy interests. That privacy is essential to human dignity, a basic value underlying the Charter, has also been recognized. Our righl to security of the person under $\mathrm{s} .7$ has been found to include protection from psychological trauma which can be occasioned by an invasion of our privacy. Certainly, the breach of the privacy of a sexual assault plaintiff constitutes a severe assault on her psychological well-being. Section 8 also reveals that the Charter is clearly premised on a respect for the interests of individuals in their privacy. ${ }^{133}$

In Schreiber v. Canada (Allorney General), ${ }^{134}$ although disagreeing on whether a reasonable expectation of privacy existed, the justices reiterated this conception. For example, Lamer C.J.C. stated:

This Court has said a great deal about how expectations of privacy, and their reasonableness, can be ascertained. In my view, the single most important idea that emerges from the jurisprudence is that expectations of privacy must necessarily vary with the context. This is inherent in the idea that privacy is not a right tied to property, but rather a crucial element of individual freedom which requires the state to respect the dignity, autonomy and integrity of the individual. The degree of privacy which the law protects is closely linked to the effect that a breach of that privacy would have on the freedom and dignity of the individual. ${ }^{135}$

Finally, R. v. Dyment ${ }^{136}$ is significant. In Dyment, the Court combined several of the conceptions to address privacy. ${ }^{137}$ In identifying those situations where society should be

[1995] 4 S.C.R. $411\left[O^{\prime} \mathrm{Commor}\right]$.

[1997] I S.C.R. 157 [Ryan].

In $O^{\prime}$ Commor (supra noie 130), an accused in a sexual assault case wanted access to counselling records of the complainants held by third parties. Ryan, ibid., involved a similar request for disclosure by the defendant in a civil suit for sexual assault brought by his victim. Both cases are considered important from a constitutional point of view as some consider $O^{\circ}$ Connor and Ryan as establishing $s .7$ of the Charter as the constitutional source for a right to privacy. Indeed, L'Heureux-Dubé J. said as much in Ryan.

Supra note 131 at para. 80.

Supra note 12.

Jbid. at 854.

Supra note 3.

To be fair, several cases have used terminology associated with different conceptions. They do so only in passing and generally only after emphasizing another conception. In Mchermey, supra note 67, for example, La Forest J. commented on an individual's autonomy at 148:

When a patient approaches a physician for health care, he or she discloses sensitive information concerning personal aspects of his or her life. The patient may also bring into the relationship information relating to work done by other medical professionals. The policy statement of the Canadian Medical Association cited earlier indicates that a physician cannot obtain access to this information without the patient's consent or a court order. Thus, at least in part, medical records 
most alert to privacy considerations, La Forest J. adopted different zones of privacy: those involving territorial or spatial aspects, those related to the person and those that arise in the information context. ${ }^{138}$ In doing so, several conceptions are involved. Justice La Forest stated:

As noted previously, territorial claims were originally legally and conceptually tied toproperty, which meamt that legal claims to privacy in this sense were largely confined to the home. But as Westin, supra, at p. 363. has observed. "[t]o protect privacy only in the home ... is to shelter what has become, in modem society, only a small part of the individual's daily environmental need for privacy". Humler v. Sourham Inc. ruptured the shackles that confined these claims to property. Dickson J., at p. 15\%, rightly adopted the view originatly put forward by Stewarn J. in Katz v. United States, 389 U.S. 347 (1967), at p. 351, that what is protected is peoplc, not places. This is not to say that some places, because of the nature of the social interactions that occur there, should not prompt us to be especially alert to the need to protect individual privacy.

Finally, there is privacy in relation to information. This too is based on the notion of the dignity and integrity of the individual. As the Task Force pul it (p. 13): "This notion of privacy derives from the assumption that all in lormation about a person is in a fundamental way his own, for him to communicale or retain for himself as he sees fit." In modem socicty, especially, retention of in formation about oneself is extremely important. We may, for one reason or another, wish or be compelled to reveal such information, but situations abound where the reasonable expectations of the individual that the information shall remain confidential to the persons to whom, and restricted to the purposes for which it is divulged, must be protected. ${ }^{139}$

As demonstrated previously, one of the main criticisms of the current conceptions of privacy is that they depend upon and serve the concept of privacy as a liberty issue which, in turn, is conceived of as a form of licence. As such, privacy - in so far as it protects individual liberties - will continually be in tension with other conflicting liberty interests. As the history in the U.S. has demonstrated, where privacy competes with other liberties, privacy often loses. The result is incoherent conceptions of privacy which only partly explain the myriad of ways that privacy presents itself in a modern world. If the current conceptions, or any combination of them, are unsatisfying, a different approach to conceptualizing privacy has been suggested, one that decides privacy on a case-by-case basis. It is to this alternative approach that I now turn.

\section{B. A Pragmatic Approach to Conceptualizing Phivacy}

Not surprisingly, Solove accepts that the current conceptions of privacy do not work: "The [current] top-down approach [to conceptualizing privacy] of beginning with an overarching

contain information about the patient revealed by the patient, and information that is acquired and recorded on behalf of the patient. Of primary signilicance is the fact that the records consist of information that is highly private and personal to the individual. It is information that goes to the personal integrity and autonomy of the patient.

Similarly, in Plamt, supra note 11, Sopinka J. noted in passing, the underlying values of dignily, integrity and autonomy are protected by s. 8 of the Charter. 
conception of privacy designed to apply in all contexts oflen results in a conception that does not fit well when applied to the multitude of situations and problems involving privacy." 140

Solove contends that privacy problems involve disruptions to certain practices, not isolated events, and should be seen as a dimension of these practices rather than as a separate abstract concept. ${ }^{\mid 41}$ He advocates, therefore, a pragmatic approach to privacy which "turns away from universals and focuses on specific situations... [We] should act as cartographers, mapping out the terrain of privacy by examining specific problematic situations rather than trying to fit each situation into a rigid predefined category." 142 Solove summarizes his position as follows:

A pragmatic approach to the task of conceptualizing privacy should not, therefore, begin by seeking to illuminate an abstract conception of privacy, but should focus instead on understanding privacy in specific contextual situations.... Thus, the pragmatist has a unique attitude toward conceptions. Conceptions are "working hypotheses." not fixed entities, and must be created from within concrete situations and constantly tested and shaped through an interaction with concrete situations... My approach is from the bottom up mether than the top down because it conceptualizes privacy within particular contexts rather than in the abstract. ${ }^{143}$

To Solove the question is not so much whether privacy exists as it is whether privacy should be respected. If privacy impacts certain contexts or practices in a negative way, then for Solove the issue is not the existence of a privacy interest, but whether less privacy is desirable in that context. If, on the other hand, privacy furthers a desirable practice ("or is so constitutive of the practice that the practice would be impossible without it"), then privacy should be recommended. ${ }^{14+}$ It is an approach, therefore, that is less a normative theory of privacy than it is a sort of litmus test for whether privacy is or is not engaged. There are two questions which must be asked in every privacy case. First, is there a privacy interest at stake? Second, is there a fundamentally important competing right that justifies overriding the privacy interest in the case? One of the difficulties with Solove's approach is that it tries to answer both questions simultaneously.

\section{Solove's Pragmatic Approach Applied}

Solove concludes by considering a few cases using his pragmatic approach.

Solove, supra note 26 at 1099. Similarly, he states at 1096:

Although the terminologies theorists cmploy differ, most theorists strive toward the central goals of the traditional method of conceptualizing privacy: to locate the "essence" of privacy, the core common denominator that makes things privalt. The traditional method endeavors to conceptualize privacy by consiructing a category that is separale from other conceptual calcgories (such as autonomy, fredom, and so on) and that las fixed clear boundaries so we can know when things fall within the centegory or outside of it.

Jbid. at I130: "We sliould conceptualize privacy by locusing on the specilic types of disruption and the specific practices disnupted rather than looking tor the common denominator that links all of them."

142 lbid. at 1126 .

143 Ibid. at 1128-29.

144

lbid. at 1144 . 
In McNamara v. Freedom Newspapers, ${ }^{145}$ a newspaper published a photo of a high school soccer player's genitalia that he inadvertently exposed while running on the soccer field. The student sued under the American tort of public disclosure of private facts. The Court held that the student's case should be dismissed because the "picture accurately depicted a public event and was published as part of a newspaper article describing the game. At the time the photograph was taken, [the student] was voluntarily participating in a spectator sport at a public place."146

The Court based its decision on a conception of privacy as concealing private facts. ${ }^{147}$ For Solove, the Court ought to have approached the issue by looking at what social practices ought to be either protected or prohibited by the privacy claim:

\footnotetext{
The answer, I believe, is that social practices have developed to conceal aspects of life that we find animallike or disgusting as well as activities in which we feel particularly vulnerable and weak. We scrub, dress, and groom ourselves in order to present ourselves to the public in a dignified manner. We seek to cover up smells, discharge, and excretion because we are socialized into viewing them with disgust. We cloak the nude body in public based on norms of decorum. These social practices, which relegate these aspects of life to the privale sphere, are deeply connected to human dignity.... [O]ne form of torture is to dehumanize and degrade people by making them dirty, stripping them. forcing them to eliminate waste in public, and so on. When social practices relating to dignity are disnupted, the result can be a severe and sometimes debilitating humiliation and loss of self-estcem. Therefore, the fact that the student's genitalia was exposed to the public may have eliminated its secrecy, but the injury was not one of lost secrecy. The fact that the exposure oceurred in a public place should have been treated as relatively unimportant. ${ }^{148}$
}

Although substantive criticisms of Solove's approach will be offered below, his reasoning in this case is suspect on two alternative grounds. On the one hand, Solove's argument defending the runner's privacy appears to be based on the same current conceptions of privacy that he rejected earlier. His terminology - dignity and self-esteem - invokes the same conceptions of privacy which Solove conceded are incoherent. If this is so, then Solove's defence of privacy must fail for the same criticisms mentioned earlier.

Alternatively, if privacy is simply a matter of context, is privacy really engaged here? The exposure may be embarrassing, and the runner would presumably hope that the newspaper would not print such a picture simply for its titillating detail, but is it private? What practice would be disrupted if the picture is printed? Would the picture prevent the runner from pursuing a path he hopes would define him? Would the runner recoil into his own world, shunning the possibility of athletic glory in favour of a seat in the stands? Would he shun all forms of exercise or sport, or only those done in public? I doubt it, but this assumption belies a fundamental difficulty with Solove's approach. It re-introduces a form of "intuitive analysis" back into the argument which, as mentioned previously, is unhelpful.

802 S.W.2d. 901 (Tex. Ct. App. 1991).

lbid. at 905.

Solove, supra note 26 at 1 147: "Since the photograph was taken outside and in public, the student could not claim that an image of his exposed genitals was a private matter."

thid. al 1148-49 [ footnotes omitled]. 
In Nader v. General Motors Corp., ${ }^{\text {14" }}$ Ralph Nader, an outspoken critic for consumer safety, had for many years criticized the safety of GM automobiles: "General Motors interviewed Nader's friends and acquaintances to learn the private details of his life, made threatening and harassing phone calls, wiretapped his telephone and eavesdropped into his conversations, hired prostitutes to [attempt to] entrap him into an illicit relationship, and kept him under pervasive surveillance while outside in public places." 150 The Court considered each of the complaints separately as a privacy complaint. With the exception of the wiretapping, the Court concluded that no privacy rights were infringed. With regards to the surveillance, however, the Court concluded that surveillance could be so "overzealous" as to render it actionable. ${ }^{151}$

Solove objects to the Court considering the acts in isolation, suggesting that the Court

lost sight of the forest for the trees ["[b]y slicing off parts of the case and compartmentalizing them into categories, the Court impeded a jury's ability to consider the lull situation" 1. . The purpose of Ciencral Motors' plan was to employ its considerable power in a campaign to disrupt Nader's personal aftairs. The Court should have focused on the way in which the company's actions aimed to disrupt Nader's life, and the paramount social importance of avoiding such exercises of power designed to deter, harass, and discredit individuals, especially ones who are allempting to raise important social and political issues. ${ }^{153}$

By considering the context of this case, as opposed to the alleged invasions of privacy in isolation, Solove concludes that the social practices disrupted by the facts of this case social and political speech - established a general violation of Nader's privacy. Nothing more should be required to assert privacy.

With respect, why? With the exception of the wiretapping (which is also illegal), what privacy interest is engaged? Nader's choices, like those of General Motors, have consequences: to whom should he divulge intimate details of his life, in what acts or activities should he engage in public? ${ }^{154}$ Depending on what use GM could make of any discreditable conduct that Nader engaged in, there are a number of actionable remedies available to Nader, without having to resort to privacy. Defamation, extortion, trespass and nuisance readily come to mind. There are legitimate causes of action which exist independent of privacy. Do we have to torture privacy to get relief, when other recognizable causes of action exist? By attempting to have privacy be all things to all people. Solove's approach risks trivializing privacy for everybody.

255 N.E.2d 765 (N.Y. 1970).

Solove's summary of the issue. (supra note 26 at 1149 ).

Posner summarizes surveillance cases as follows: "The common thread running through the cases in which the courts have held that ostentatious surveillance was tortious is that the survillance exceeded what was reasonably necessary to uncover private information and became a method of intimidation. embarrassment, or distraction" (Posner, supra nole 21 at 420). One wonders why privacy is involved if these other recognized causes of actions adequately respond to these situations.

Solove, supra note 26 at 1151.

Ibid. at 1150.

As Fried states, "[o]ne does not trust machines or animals; one takes the fullest economically feasible precautions against their going wrong. Often, however, we cheose to trust people where it would be safer to take precautions - to watch them or require a bond from them" (supra note 26 at 486). If only it were that simple. 


\section{A Criticism of Solove's Pragmatic Approach}

The critics of the prevailing conceptions of privacy are correct: they argue, persuasively in my view, that the other conceptions all attempt to define the fundamental characteristic, or common denominator, in privacy claims to be the protection of a liberty as a licence interest. The goal has been, obviously, to attempt to define privacy with sufficient precision yet retain flexibility to deal with the rapid pace of technology and the implications for privacy that arise as a result. The consequence, unfortunately, has been conceptions of privacy that are too broad, too narrow or both.

Accordingly, it is easy to see why Solove's pragmatic approach has appeal. Perhaps no single conception of privacy is indeed coherent and, therefore, we ought to abandon the search for the core value of privacy in favour of a pragmatic approach where privacy cases are considered on a case-by-case basis to be determined in their respective context. That is, maybe positivism is the answer, at least for privacy, ${ }^{155}$ because no conception of privacy that assumes an inherent core value is possible:

\footnotetext{
Runald Dworkin, one of the principal proponents of intrinsic value, argues that certain things "are valuable in themselves and not just for their utility or for the pleasure of satisfaction they bring us".... However, along with other scholars, I contend that privacy has an instrumental value-namely, that it is valued as a means for achicving certain other ends that are valuable.... In contrast to many conceptions of privacy, which describe the value of privacy in the abstract, J contend that there is no overarching value of privacy. ${ }^{\text {IS6 }}$
}

1 do not share this view. My view is that the conceptions have thus far simply failed to identify the common denominator-the hub of the privacy wheel, to use Solove's metaphor. If'liberty - or some manifestation thereof - is not the core value of privacy, does that mean that some other intrinsic value at its core does not exist?

Second, although positivism has some intuitive appeal, ${ }^{157}$ I cannot agree that there is no conceptual connection between law and morality - that law is simply "morally neutral" and

Solove, supra note 26. Evidence that Solove's approach rests upon a positivistic view of the law include: (at 1 126) "pragmatism turns away from universals and focuses on specific situations"; (at 1127) rejects the notion, at least for privacy, "that there are objective and universal tnuths that exist prior to, and independently of, experience"; (at 1144 ) "If privacy impacts the practice in a negative way, then less privacy would be desirable. If privacy furthers a desirable practice (or is so constitutive of the practice that the practice would be impossible without it), then privacy should be recommended." Quaere: isn't this a retum to the length of the Chancellor's foot?

Ibid. at II 45, quoting Ronald Dworkin, Life's Dominion: An Argumen About Abortion, Euthanasia, and Individual frredom (New York: Knopf, 1993) at 69-70 [footnotes omitted].

13: See Brian H. Bix, "Legal Positivism" in Martin P. Golding \& William A. Edmundson, eds., The Blackwell Guide to the Philosophy of Lan and Legal Theony (Malden, Mass.: Blackwell, 2005) 29 at 33:

(1) it carries the power of a simple model of law (if, like other simple models of human behaviour, it sometimess suffers a stiff cost in distortion); (2) its focus on sanctions, which seems, to some, to properly emphasize the importance of power and coercion to law; and (3) because it does not purport to reflect the perspective of a sympathetic participant in the legal system, it does not risk sliding towards a moral endorsement of the law. 
"descriptive" - as positivism attempts to do. If law requires social consensus ${ }^{158}$ and depends only on its source or pedigree for its validity - and as a consequence there are no inherent or natural rights which exist apart from some external source - then positivism suffers, in my view, from majoritarianism and intuitionism. Both are unsatisfying from the aspect of privacy. With regards to the former, one must prevail upon the will of the majority. As Dworkin has suggested, majoritarianism is not the proper basis for protecting unpopular or minority interests in a free and democratic society:

Constitutionalism - the theory that the majority must be restrained to protect individual rights - may be a good or bad political theory. but the United States has adopted that theory, and to make the majority judge in its own cause seems inconsistent and unjust. So principles of faimess seem to speak against, not for, the argument from democracy. ${ }^{159}$

Further, having to rely upon judicial activism is also unacceptable. The objections are threefold. First, pleas for judicial activism similarly rely on the judge's view of societal values, or of the will of the government if deferring to legislation, which is simply majoritarianism from a judicial perspective. Second, it would seem likely that an intuitionist analysis as contemplated by Whitman would creep into judicial activism. Third, if rights do not exist until recognized by the courts or the legislature, yet judges have discretion where the "law" is vague, how can people know with certainty what their rights and obligations are before finding that they have none or, worse, have violated some heretofore unrecognized duty? Making law, and therefore rights and duties, and applying it retrospectively, is unacceptable. ${ }^{160}$

It must be acknowledged, on the other hand, that a rights-based view of the law - with law and morality conceptually connected - is troublesome for many lawyers and judges:

A great many lawyers are wary of talking about moral rights, even though they lind it easy to talk about what is right or wrong for government to do, because they suppose that rights, if they exist at all, are spooky sorts of things that men and women have in much the same way as they have non-spooky things like tonsils. But the sense of rights I propose to use does not make ontological assumptions of that sort: it simply shows a

Ibid. at 35:

As discussed above, H.L.A. Hart had argued that all (modern or malure) legal systems have secondary rules-rules about rules, rules that allow for the identilication, modification, and application of "primary rules"... Most significantly within Hart's analysis, legal systems have a "Rule of Recognition," which comprises the basic criteria of legal validity within the legal system in question: the Rule of Recognition "will specily some feature or features possession of which by a suggested rule is taken as a conclusive affirmative indication that it is a rule of the group to be supported by the social pressure it exerts." The basic role or nature of the Rule of Recognition is estublished by the legal system's being a normative system: a structured system of "ought" statements.... Under Hart's approach, one looks th the behavior of legal oflicials (especially judges) to determine what the ultimate criteria of vulidity are. (The sovereign plays a similar role in Austin's command theory. All the valid norms in the legal system, according to this approach, can be traced back to a direct or indirect command by the sovercign (indirect commands include the sovereign's authorization that judges can make new law in the sovereign's name).) 
claim of right to be a special, in the sense of a restricted, sort of judgment about what is right or wrong for governments to do. ${ }^{161}$

Spooky though they may be, for rights to have substance, they must be inherent or natural and not dependent upon some external source: "It must be a theory that is based on the concepts of rights that are natural, in the sense that they are not the product of any legislation, or convention, or hypothetical contract": ${ }^{162}$ they are not "[gifts from] God, or an ancient ritual, or a national sport."163

If privacy is not inherent to individuals, and there are no privacy principles per se, then any developments in privacy require legislative decree. Our quest becomes simply to champion legislative reform to address particular contexts where privacy interests are at issue. We become beholden to political will and judicial discretion. ${ }^{164}$ Solove subscribes to this position with his contention that privacy has no inherent value on its own, only an instrumental value, namely, "that it is valued as a means for achieving certain other ends that are valuable." ${ }^{\prime 65}$ For those who subscribe to Dworkin's view that rights are inherent, Solove's pragmatic approach is unsatisfying. Further, that privacy is not a "right" seems contradictory to most jurisprudence which recognizes privacy - in some form or another - as a fundamental right worthy of constitutional protection.

\section{Conclusion}

Privacy law finds itself in a most distressing state. Inconsistency and conflict are evident in both the jurisprudence and the literature on privacy. At first glance, this unhappy state of affairs appears to arrive from a lack of consensus on the core liberty or liberties that privacy strives to protect. If we want to protect privacy, so the argument goes, then we have to ground it in something other than an inchoate, inarticulate right. We have to discover, the argument continues, the fundamental kinds of activities which people would invariably point to as requiring privacy. This approach forces privacy discourse into a debate about which liberty interests - or action verbs - are deserving of protection. The current conceptions of privacy do just that. In doing so, however, the conceptions are invariably too broad or too narrow and fail to explain the place of privacy in the modern world. They offer an intuitive approach of what makes things "private" and falter when intuitive commonality does not exist.

The difficulties with the current approach lie much deeper than simply trying to identify those things that ought to be private. Exposed is a fundamental failure in the discourse to distinguish between the concept of privacy and any particular conception of privacy based upon that concept. The inadequacy of the prevailing conceptions of privacy is that they are

Ibid. at 139.

Ibid. at 176 [emphasis in original].

Biil. at 198.

An approach rejected by Ronald Dworkin when discussing constitutional debate in "Unenumcraled Rights: Whether and How Roe Should be Overruled" (1992) 59 U. Chi. L. Rev. 381 at 393: "Nor should we waste any more time on the silly indulgence of American legal academic life: the philosophically juvenile claim that, since no such formula exists [for explaining "bad" constitutional decisions], no one conception of constitutional equality and liberty is any better than another, and adjudication is only power or visceral response."

Solove, supra note 26 at 1145. 
all based on an underlying concept of privacy that is flawed. While a more abstract concept of privacy - that there is certain information about ourselves that is not open for public consumption - remains incontestable, the standing conceptions of privacy suggest that there are certain activities in which we engage that are not open for public consumption. So conceptualized, individuals are, or should be, free to do according to their own lights. As conceived, then, the prevailing concept of privacy is of privacy as libery. The prevailing conceptions of this concept of privacy are simply arguments about what activities ought to be private - abortions, possession of pornography or unpopular material, associations with unpopular groups: the list could go on ad infinitum. Privacy, so conceived, finds itself continually at odds with both state and other individual interests. This is a conflict that privacy usually loses and leaves one with the impression that privacy is not that valuable as a right.

Is it possible to conceptualize privacy in such a fashion that "true" privacy claims do not compete? I contend that it is indeed possible, but doing so requires us to take a step back and rethink our concept of privacy. It is time to get off the merry-go-round that marks the current privacy discourse which has seemingly accepted, without debate, that privacy is a liberty issue. With the difficulties exposed, I contend that it may be an appropriate time to consider changing the present paradigm against which privacy is evaluated. Perhaps privacy is better served if conceived of as an equality issue, not a liberty issue. Perhaps at its core privacy protects and ensures equality in the sense that we are entitled to equal concern and respect as individuals, and not that we are entitled to do as we please. Such an approach would shift away from viewing privacy as a prerequisite for preventing invasions of various liberty interests to one of maintaining conditions that will make the exercise of those liberty interests possible. So conceptualized, equality would be at the hub and the various liberty interests protected by privacy are simply spokes on the privacy wheel.

Admittedly, one would have to have a myopic view of the jurisprudence and scholarly literature to suggest that anything other than the prevailing conceptions of privacy have formed the basis for decision and argument. Nevertheless, one can clearly see the rudiments of such a paradigm shift beginning to take shape at least in Canada. Although often using "liberty" vernacular, there has been a sprinkling throughout some of the Charter jurisprudence which considers privacy issues to suggest that the overriding concern has been whether individual equality rights are harmed by an invasion of privacy, nol whether any particular liberty interest is denied. ${ }^{166}$

For example, in $O^{\prime}$ Connor, supra note 130 at 488-89, L'Heureux-Dubé J. stated:

As I noted in Osolin. uninhibited disclosure of complainants' private lives indulges the discriminatory suspicion that women and children's reports of sexual victimization are uniquely likely to be fabricated. Put another way, if there were an explicit requirement in the code requiring corroboration before women or children could bring sexual assault charges, such a provision would raise serious concerns under s. Is of the Charter. In my view, a legal system which devalues the evidence of complainants to sexual assault by de facto presuming their uncreditworthiness would raise similar concerns. It would not rellect. lar less promote, "a scciety in which all are secure in the knowledge that they are recognized at law as human beings equally deserving of concern, respect and consideration" [citations omitted. emphasis in original].

Justice L'Ileureux-Dube subsequently completed (at 490) the connection between privacy and equality: All of these factors, in my mind, justify concluding not only that a privacy analysis creates a presumption against ordering production of privale records, but also that ample and meaningful consideration must be given to complainants' equality rights under the Charter when formulating an appropriate approach to the production of complainants' records. Consequently, I have great 
A concept of privacy as equality has tremendous appeal. Whereas liberty issues will often compete, the more fundamental right - equality - is not in conflict. Indeed, it is something of a non sequitur to suggest competing equality interests. How can two individuals be afforded equal concern and respect if one's equality must take preference over another's? Accepting privacy as an equality issue, one would then be in a position to articulate a particular conception of privacy which would determine when equality, and therefore privacy, is engaged. ${ }^{167}$

A likely consequence of adopting a different paradigm to privacy as equality may be to restrict privacy. But privacy cannot be all things to all lawyers. As stated over 100 years ago by the "founders" of the privacy right in the U.S.:

That the individual shall have full protection in person and in property is a principle as old as the common law; but it has been found necessary from time to time to define anew the exact nature and extent of such protection. Political, social, and economic changes entail the recognition of new rights, and the common law, in its etemal youth, grows to meet the demands of socicty. ${ }^{168}$

Perhaps, given the difficulties exposed in privacy law today, it is time again to consider anew how privacy is conceived. By limiting the ambit of privacy, we may indeed strengthen it.

sympathy for the observation of Hill J. in $R$. v. Barbosa to this effect (at 141):

In addressing the disclosure of records, relating to past treatment. analysis, assessment or care of a complainant, it is necessary to remember that the pursuit of full answer and defence on behalf of an accused person should be achieved without indiscriminately or arbitrarily eradicating the privacy of the complainant. Sisfemic revictimization of a complainam fosters disrepute for the criminal justice system [citation omitted, emphasis in original].

Similarly, McLachlin J. (as she then was) emphasized in Ryan, supra note 131 at 175-76, the connection between privacy and equality as a result of an unreasonable disclosure of personal information of a victim of sexual assault:

As noted, the common law must develop in a way that reflects emerging Charrer values. It follows that the factors balanced under the fourth part of the test for privilege should be updated to reflect relevant Charrer values. One such value is the interest aflirmed by s. 8 of the Charfer of each person in privacy. Another is the right of every person embodied in s. 15 of the Charter to equal treatment and benefit of the law. A rule of privilege which fails to protect confidential doctor/patient communications in the context of an action arising out of sexual assault perpetuates the disadvantage felt by victims of sexual assault, often women. The intimate nature of sexual assault heightens the privacy concems of the victim and may increase, if automatic disclosure is the rule, the difficulty of obtaining redress for the wrong. The victim of a sexual assault is thus placed in a disadvantaged position as compared with the victim of a different wrong. The result may be that the victim of sexual assaull does not obtain the cqual benefit of the law to which s. 15 of the Charter entitles her. She is doubly victimized, initially by the sexual assault and later by the price she must pay to claim redress- redress which in some cases may be part of her program of therapy. These are factors which may properly be considered in determining the interests served by an order for protection from disclosure of confidential patient-psychiatrist communications in sexual assault cases.

I will make such an attempt in a subscquent essay, where I will draw on equatity and human rights jurisprudence to suggest that the potential for discrimination in the sense of stereotyping. historical disadvantage, and vulnerability to political and social prejudice would invariably violate an individual's right to equal concem and respect under any reasonable conception of equality. Therefore, where there is the potential for discrimination, privacy will be triggered. This, in my view, is why we need privacy-not to protect any particular activity or liberty as license, but to safeguard our equality. Without equality, meaningful liberty is illusory. 